\title{
PHYLOGENETIC AND PHYTOGEOGRAPHICAL RELATIONSHIPS IN MALOIDEAE (ROSACEAE) BASED ON MORPHOLOGICAL AND ANATOMICAL CHARACTERS
}

\author{
JUAN JOSÉ ALDASORO ${ }^{1}$, CARLOS AEDO ${ }^{1}$ \& CARMEN NAVARRO ${ }^{2}$
}

\begin{abstract}
SUMMARY
Phylogenetic relationships among 24 genera of Rosaceae subfam. Maloideae and Spiraeoideae are explored by means of a cladistic analysis; 16 morphological and anatomical characters were included in the analysis. Published suprageneric classifications and characters used in these classifications are briefly reviewed. Additionally, some new features are here reported, such as seed shape, presence or absence of endosperm, and number of cell layers in the seed coat and in the endosperm. Parsimony analyses indicate that Eriobotrya and Rhaphiolepis form a well-supported clade that is the sister to the remainder of the subfamily. This result is in agreement with published ITS sequence data. Other clades are not supported, with the exception of the group Amelanchier-Peraphyllum-Malacomeles. Results of several studies point toward North America as centre of origin for Maloideae, considering the distribution of closely related Spiraeoideae such as Vauquelinia and Lindleia. A non-metric multidimensional scaling analysis of Takhtajan's biogeographic regions was carried out using presence/ absence of genera as characters. Eastern Asia is a centre of diversity from which the number of shared taxa decreases in several directions. This can be associated with the retreat of many taxa belonging to the Early Tertiary tropical-subtropical flora towards the refuges of China, Indochina and Malaysia, after wet-temperate forests were progressively transformed during the Neogene, which seems to be the case of Eriobotrya and Rhaphiolepis. Finally, Osteomeles and Chamaemeles were postulated as long-distance dispersion events while Hesperomeles could have originated in North America and migrated into north-western South America.
\end{abstract}

Key words: Rosaceae, Maloideae, morphology, anatomy, phylogenetic and phytogeographical relationships.

\section{INTRODUCTION}

Maloideae is a very important and intensively studied subfamily of the Rosaceae. Most of the genera are from temperate regions of the Northern Hemisphere, but there is an extension into southern Asia, Hesperomeles grows in South America, and Osteomeles reaches several South Pacific islands. The most significant character state of the subfamily are the pome fruits and the basic chromosome number $\mathrm{x}=17$ (Sax, 1931).

In the classification of subfam. Maloideae used by Robertson et al. (1991), 28 genera were included (Table 1). However, those generic concepts were not followed by all authors. Gabrielian (1978) and Phipps et al. (1990) circumscribed Sorbus in a broad

1) Real Jardín Botánico, Consejo Superior Investigaciones Científicas, Plaza de Murillo 2, 28014 Madrid, Spain.

2) Departamento de Biología Vegetal II, Facultad de Farmacia, Universidad Complutense, 28040 Madrid, Spain. 
Table 1. Comparison of different treatments of Maloideae at the generic level.

\begin{tabular}{|c|c|c|c|c|}
\hline & Possible genera & Koehne (1890) & $\begin{array}{l}\text { Robertson et al. } \\
\text { (1991) }\end{array}$ & $\begin{array}{l}\text { Aldasoro et al. } \\
\text { (this paper) }\end{array}$ \\
\hline \multirow{25}{*}{ 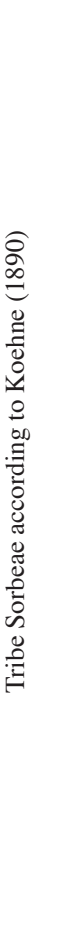 } & Amelanchier Medik. & Amelanchier & Amelanchier & Amelanchier \\
\hline & Aria (Pers.) Host & Aria & Aria & Sorbus subg. Aria \\
\hline & Aronia Medik. & Aronia & in Photinia & in Photinia \\
\hline & Chaenomeles Lindl. & Chaenomeles & Chaenomeles & Chaenomeles \\
\hline & Chamaemespilus Medik. & in Aria & Chamaemespilus & in Sorbus subg. Aria \\
\hline & Chloromeles (Decne.) Decne. & in Malus & in Malus & in Malus \\
\hline & Cormus Spach & Cormus & Cormus & Sorbus subg. Cormus \\
\hline & Cydonia Mill. & Cydonia & Cydonia & Cydonia \\
\hline & Docynia Decne. & Docynia & Docynia & Docynia \\
\hline & $\begin{array}{l}\text { Docyniopsis (C.K. Schneid.) } \\
\text { Koidz. }\end{array}$ & & Docyniopsis & Malus sect. Docyniopsis \\
\hline & Eriobotrya Lindl. & Eriobotrya & Eriobotrya & Eriobotrya \\
\hline & Eriolobus (DC.) M. Roem. & Eriolobus & Eriolobus & in Malus \\
\hline & Heteromeles M. Roem. & in Photinia & Heteromeles & Heteromeles \\
\hline & Malacomeles (Decne.) Engl. & in Amelanchier & Malacomeles & Malacomeles \\
\hline & Malus Mill. & Malus & Malus & Malus \\
\hline & Micromeles Decne. & Micromeles & in Aria & in Sorbus subg. Aria \\
\hline & Peraphyllum Nutt. & Peraphyllum & Peraphyllum & Peraphyllum \\
\hline & Photinia Lindl. & Photinia & Photinia & Photinia \\
\hline & Pourthiaea Decne. & in Photinia & in Photinia & in Photinia \\
\hline & $\begin{array}{l}\text { Pseudocydonia (C.K. Schneid.) } \\
\text { C.K. Schneid. }\end{array}$ & in Chaenomeles & Pseudocydonia & Pseudocydonia \\
\hline & Pyrus L. & Pyrus & Pyrus & Pyrus \\
\hline & Rhaphiolepis Lindl. & Rhaphiolepis & Rhaphiolepis & Rhaphiolepis \\
\hline & Sorbus L. & Sorbus & Sorbus & Sorbus \\
\hline & Stranvaesia Lindl. & Stranvaesia & in Photinia & in Photinia \\
\hline & Torminalis Medik. & Torminaria & Torminalis & Sorbus subg. Torminalis \\
\hline \multirow{8}{*}{ 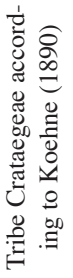 } & Chamaemeles Lindl. & Chamaemeles & Chamaemeles & Chamaemeles \\
\hline & Cotoneaster Medik. & Cotoneaster & Cotoneaster & Cotoneaster \\
\hline & Crataegus L. & Crataegus & Crataegus & Crataegus \\
\hline & Dichotomanthes S. Kurtz & & Dichotomanthes & Dichotomanthes \\
\hline & Hesperomeles Lindl. & Hesperomeles & Hesperomeles & Hesperomeles \\
\hline & Mespilus L. & Mespilus & Mespilus & Mespilus \\
\hline & Osteomeles Lindl. & Osteomeles & Osteomeles & Osteomeles \\
\hline & Pyracantha M. Roem. & Pyracantha & Pyracantha & Pyracantha \\
\hline
\end{tabular}

sense, to include Aria, Chamaemespilus, Cormus, and Torminalis. Phipps et al. (1990) also considered Malus in a broad sense, i.e. to include Eriolobus and Docyniopsis, and accepted Aronia and Stranvaesia at generic rank. We have followed the system of Robertson et al. (1991), except that we include Chamaemespilus in Sorbus subg. Aria according to Phipps et al. (1990) and Eriolobus in Malus according to Rehder (1920, 1940) (Table 1).

Maloideae was formerly treated as a separate family by Gray (1821) under the name Pomaceae, a position that has had little support. According to Weber (1964) this group should be considered as a subfamily of Rosaceae and the name Pomoideae replaced by Maloideae. Neither Lindley (1822) nor Decaisne (1874), after a thorough study 
of this group, proposed any subgroup classification. Two different classifications of subfam. Maloideae have been proposed: Koehne (1890) divided the subfamily in tribes Crataegeae, wherein the ovary wall hardens and each carpel develops into a separate pyrene and Sorbeae, with a membranous to cartilaginous carpellary wall and connate carpels. However, according to Kalkman (1988) this subfamily should be divided into two informal groups: Maleae which has only two (rarely one) ovules per carpel as opposed to several ovules in the Cydonia group. Recent studies based on morphology (Phipps et al., 1991; Rohrer et al., 1991, 1994), wood anatomy (Zhang, 1992), and DNA (Campbell et al., 1995) do not support either of these divisions.

Past morphological studies included general vegetative habit and branching, bark, dormant buds, foliage, inflorescences, flower and pome features (Sterling, 1965a, b, c; Phipps et al., 1991; Rohrer et al., 1991, 1994). This generated a large set of characters from which Phipps et al. (1991) used some for their cladistic analysis. We concentrated our efforts on those which showed a presumably lower level of homoplasy. To supplement this set of characters we surveyed some anatomical characteristics of pomes and seeds, which seemed to be informative.

The pome has several features which provided more information, such as: the shape and distribution of sclereids and their groupings and the structure of pyrenes and pome locules (Gabrielian, 1978; Iketani \& Ohashi, 1991; Rohrer et al., 1991, 1994; Aldasoro et al., 1998a, b). Taxonomically important variation in the seed structure of Rosaceae was discussed by Péchoutre (1902) and Danilova (1996). The most significant characters were seed size and shape, seed coat width, and presence and size of endosperm. According to Péchoutre (1902) the presence of endosperm is widespread in all groups of Maloideae and several other Rosaceae.

Cladistic and molecular systematic essays carried out to clarify the phylogeny of Maloideae came across with great difficulties caused by hybridization between genera in old and strongly homoplasic groups (Phipps et al., 1991; Campbell et al., 1995). Phipps et al. (1991) obtained trees with a low consistency index. Kalkman (1988) proposed a Gondwanic origin for Rosaceae and Thorne (1983) suggested that Kageneckia, with $2 \mathrm{n}=34$, might be part of an ancient Gondwana stock which could have some relation with the origin of the subfamily. This could shift the origin to the Early Palaeogene or even to the end of the Cretaceous. Other evidences point toward a North American origin, such as the distribution of several closely related Spiraeoideae (Kageneckia, Vauquelinia and Lindleia) or the presence of a fossil related to these taxa: Paleorosa similkameensis (Eocene of British Columbia; Basinger, 1976).

Maloideae were already well diversified during the Early Tertiary. Several fossil remains of Amelanchier, Cotoneaster, Crataegus, Eriobotrya, Heteromeles, Lyonothamnus, Malus, Mespilus, Peraphyllum, Photinia, Pyracantha, Pyrus, Rhaphiolepis, Sorbus and Vauquelinia were reported from lower Eocene to Pliocene in North America, Asia, and Europe (Zhilin, 1974, 1989; Taylor, 1990) (Table 2). Unfortunately, those data are not sufficient to explain the grounds of current geographical distribution of Maloideae: some of the genera are not reported as fossils (i.e., Osteomeles, Chamaemeles, Dichotomanthes, Cydonia, Pseudocydonia or Chaenomeles), others are only reported in the Neogene (i.e., Eriobotrya and Rhaphiolepis) and some significant regions have no meaningful fossil record (i.e., Malaysia, Indo-China, and North Africa). Most Maloideae reports are based only on fossil leaves and should be viewed with some caution 
Table 2. Selected fossil records of Maloideae and related Spiroideae (Lyonotamnus, Vauquelinia and possibly Paleorosa).

\begin{tabular}{|c|c|c|c|}
\hline Age & Geographic area & Taxon & Reference \\
\hline \multirow{7}{*}{ 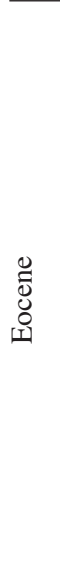 } & $\begin{array}{l}\text { North America (Thunder } \\
\text { Mountain, Idaho) }\end{array}$ & $\begin{array}{l}\text { Sorbus oblongifolia Axelrod, Malus } \\
\text { collardii Axelrod, Amelanchier } \\
\text { deweyensis Axelrod }\end{array}$ & Axelrod, 1998 \\
\hline & North America (NE Washington) & Photinia spec. & Wolfe \& Wehr, 1987 \\
\hline & $\begin{array}{l}\text { North America (Allenby } \\
\text { Formation, British Columbia, } \\
\text { Canada) }\end{array}$ & Paleorosa similkameensis Basinger & $\begin{array}{l}\text { Basinger, 1976; } \\
\text { Cevallos-Ferriz et al., } \\
1993\end{array}$ \\
\hline & $\begin{array}{l}\text { North America (Green River } \\
\text { Formation, Colorado) }\end{array}$ & $\begin{array}{l}\text { Vauquelinia liniara MacGinitie, V. colo- } \\
\text { radensis (Knowlton) MacGinitie, Malus } \\
\text { pseudocredneria (Cockerell) MacGinitie, } \\
\text { Peraphyllum septentrionale (Lesq.) } \\
\text { Axelrod, Crataegus spec. }\end{array}$ & MacGinitie, 1969 \\
\hline & North America (Gulf of Alaska) & Heteromeles cuprovalis (Axelrod) Wolfe & Wolfe, 1977 \\
\hline & China (Litang, Relu Formation) & Sorbus litangensis S. Guo & Guo, 1986 \\
\hline & China (Weinan, Shensi) & Crataegus spec. & Jun-rong, 1965 \\
\hline \multirow{10}{*}{ 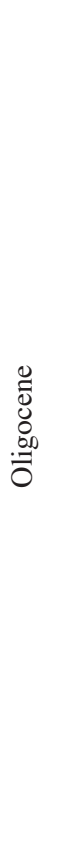 } & $\begin{array}{l}\text { North America (Creede } \\
\text { formation, Colorado) }\end{array}$ & $\begin{array}{l}\text { Peraphyllum septentrionalis (Lesq.) } \\
\text { Axelrod, Sorbus potentilloides (Knowlton) } \\
\text { Axelrod, Crataegus creedensis Axelrod }\end{array}$ & Axelrod, 1987 \\
\hline & $\begin{array}{l}\text { North America (Florissant } \\
\text { Beds, Colorado) }\end{array}$ & $\begin{array}{l}\text { Sorbus diversifolia (Lesq.) Cockerell, } \\
\text { Vauquelinia liniare MacGinitie, } \\
\text { V. coloradensis (Knowlton) MacGinitie, } \\
\text { Malus pseudocredneria (Cockerell) MacGin }\end{array}$ & $\begin{array}{l}\text { MacGinitie, } 1953 \\
\text { nitie }\end{array}$ \\
\hline & $\begin{array}{l}\text { North America (Bridge Creek } \\
\text { Flora, Oregon) }\end{array}$ & $\begin{array}{l}\text { Amelanchier covea (Chaney) Chaney \& } \\
\text { Axelrod, A. grayi Chaney, Crataegus } \\
\text { merriamii (Knowlton) H.W. Mey. \& } \\
\text { Manchester, cf. Pyracantha spec. }\end{array}$ & $\begin{array}{l}\text { Meyer \& Manchester, } \\
1997\end{array}$ \\
\hline & $\begin{array}{l}\text { North America (Rujada Flora, } \\
\text { Oregon) }\end{array}$ & $\begin{array}{l}\text { Pyrus oregonensis R.N. Lakh., } \\
\text { Crataegus newberryi Cockerell }\end{array}$ & Lakhanpal, 1958 \\
\hline & $\begin{array}{l}\text { North America (Upper Ruby } \\
\text { River Basin, SW Nevada) }\end{array}$ & Sorbus carcharodonta Gray & Becker, 1961 \\
\hline & SW China (Jinggu, Yunnan) & Sorbus spec. & Hsu, 1983 \\
\hline & $\begin{array}{l}\text { C Asia (Ashcheayrykian, } \\
\text { N Aral region) }\end{array}$ & Sorbus gabrieljanae Budantzev & $\begin{array}{l}\text { Budantzev, 1959; } \\
\text { Zhilin, } 1989\end{array}$ \\
\hline & C Asia (Kumsuat, N Aral region) & Sorbus praetorminalis Kryshtop. \& Baik. & Takhtajan et al., 1963 \\
\hline & W Europe (Italy) & Pyracantha spec. & Eberle, 1965 \\
\hline & W Europe (Altenburg, Germany) & $\begin{array}{l}\text { Pyracantha kräuselii } \mathrm{H} \text {. Walther, } \\
\text { P. acuticarpa (C. Reid \& E. Reid) Szafer }\end{array}$ & Mai \& Walther, 1978 \\
\hline \multirow{2}{*}{ 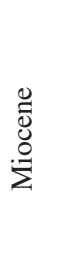 } & $\begin{array}{l}\text { North America (Purple } \\
\text { Mountain, W Nevada) }\end{array}$ & $\begin{array}{l}\text { Crataegus gracilens MacGinitie, } \\
\text { Heteromeles stenophylla Axelrod, } \\
\text { Amelanchier nevadensis Axelrod }\end{array}$ & Axelrod, 1995 \\
\hline & $\begin{array}{l}\text { North America (Buffalo Canyon } \\
\text { Flora, W Nevada) }\end{array}$ & $\begin{array}{l}\text { Amelanchier desatoyana Axelrod, } \\
\text { Heteromeles desatoyana Axelrod, } \\
\text { Crataegus middlegatei Axelrod, } \\
\text { Sorbus cassiana Axelrod, Lyono- } \\
\text { thamnus parvifolius (Axelrod) Wolfe }\end{array}$ & Axelrod, 1991 \\
\hline
\end{tabular}


Table 2 (continued)

\begin{tabular}{|c|c|c|c|}
\hline Age & Geographic area & Taxon & Reference \\
\hline \multirow{12}{*}{ 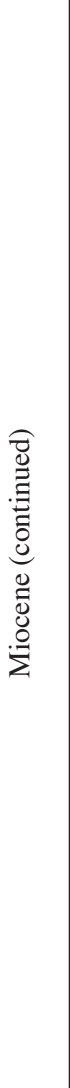 } & $\begin{array}{l}\text { North America (Pyramid Flora, } \\
\text { W Nevada) }\end{array}$ & Sorbus mcjanetii Axelrod & Axelrod, 1992 \\
\hline & $\begin{array}{l}\text { NE China (Shanwang, } \\
\text { Shandung) }\end{array}$ & $\begin{array}{l}\text { Crataegus miocuneata J. Hsu \& } \\
\text { R.W. Chaney, Eriobotrya miojaponica } \\
\text { J. Hsu \& R.W. Chaney, Malus para- } \\
\text { hupehensis J. Hsu \& R.W. Chaney }\end{array}$ & Hsu \& Chaney, 1940 \\
\hline & $\begin{array}{l}\text { SW China (Wulong Formation, } \\
\text { Xizang) }\end{array}$ & Crataegus spec. & Li \& Guo, 1976 \\
\hline & $\begin{array}{l}\text { SW China (Bangmai Formation, } \\
\text { Lincang, W Yunnan) }\end{array}$ & $\begin{array}{l}\text { Cotoneaster salicifolium Franch., } \\
\text { Stranvaesia cosmophylla, Sorbus spec. }\end{array}$ & Guo, 1993 \\
\hline & $\begin{array}{l}\text { W China (Lawula formation, } \\
\text { Tibet) }\end{array}$ & Sorbus cf. wilsoniana C.K. Schneid. & $\begin{array}{l}\text { Jun-rong \& Nai-qiu, } \\
1987\end{array}$ \\
\hline & $\begin{array}{l}\text { SE India (Cuddalore series, } \\
\text { Tamil Nadu) }\end{array}$ & Photinioxylon spec. & Lakhanpal, 1970 \\
\hline & $\begin{array}{l}\text { Japan (Itahana and Ogawa } \\
\text { formations) }\end{array}$ & $\begin{array}{l}\text { Sorbus hokiensis Ozaki, S. lesquereuxi } \\
\text { Nath., S. paleojaponica Murai, } \\
\text { S. uzenensis Huzioka }\end{array}$ & Ozaki, 1991 \\
\hline & C Asia (Ustyurt, N Aral region) & Crataegus oxiana Zhilin & $\begin{array}{l}\text { Budantzev, 1959; } \\
\text { Zhilin, } 1974\end{array}$ \\
\hline & C Asia (Samartskaia) & $\begin{array}{l}\text { Cotoneaster cf. andromedae Ung., } \\
\text { Photinia acuminata Baik., Pyrus sarma- } \\
\text { tica (Kryshtop.) Baik., Pyracantha spec., } \\
\text { Mespilus spec. }\end{array}$ & $\begin{array}{l}\text { Kryshtopovich \& } \\
\text { Baikovskaja, } 1965\end{array}$ \\
\hline & $\begin{array}{l}\text { NE Asia (Sikhote-Alin, } \\
\text { Vladivostok) }\end{array}$ & $\begin{array}{l}\text { Sorbus lanceolata Tanai \& Suzuki, } \\
\text { S. morosovae Akhmetjev, Crataegus } \\
\text { botchiensis Akhmetjev }\end{array}$ & Akhmetjev, 1973 \\
\hline & NE Asia (Primorski Kray) & Rhaphiolepis spec. & Baikovskaja, 1974 \\
\hline & $\begin{array}{l}\text { E Europe (Stare Gliwice, } \\
\text { Upper Silesia, Poland) }\end{array}$ & $\begin{array}{l}\text { Pyracantha acuticarpa Reid., Crataegus } \\
\text { cf. oxiacantha L., C. nodulosa Reid. }\end{array}$ & Szafer, 1961 \\
\hline 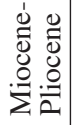 & $\begin{array}{l}\text { SW China (Teng-chong basin, } \\
\text { Yunnan) }\end{array}$ & $\begin{array}{l}\text { Sorbus aronioides Rehder in C.S. Sargent, } \\
\text { S. hemsleyii (C.K. Schneid.) Rehder in } \\
\text { C.S. Sargent }\end{array}$ & $\begin{array}{l}\text { Jun-rong \& Nai-qiu, } \\
1982\end{array}$ \\
\hline \multirow{6}{*}{$\frac{\circlearrowright}{\overbrace{0}^{\circ}}$} & $\begin{array}{l}\text { North America (Mulholand } \\
\text { Flora, California) }\end{array}$ & $\begin{array}{l}\text { Photinia sonomensis Axelrod, Lyono- } \\
\text { thamnus mohaviensis Axelrod }\end{array}$ & Axelrod, 1944 \\
\hline & $\begin{array}{l}\text { North America (Hoogendorn } \\
\text { Mine, NW Alaska) }\end{array}$ & Crataegus spec. & Wolfe, 1972 \\
\hline & Japan (Kabutoiwa formations) & $\begin{array}{l}\text { Sorbus lesquereuxi Nath., S. paleo- } \\
\text { japonica Murai, S. uzenensis Huzioka }\end{array}$ & Ozaki, 1991 \\
\hline & $\begin{array}{l}\text { E Europe (Czorsztyna, } \\
\text { W Carpathians, Poland) }\end{array}$ & $\begin{array}{l}\text { Pyrus cf. communis L., Malus sp. pl., } \\
\text { Sorbus cf. aucuparia L., Sorbus sect. Aria } \\
\text { Pers., Crataegus pentagyna Waldst. \& Kit. }\end{array}$ & Szafer, 1954 \\
\hline & $\begin{array}{l}\text { W Europe (Célas, Vallée du } \\
\text { Rhône, France) }\end{array}$ & Pyrus canescens Spach & Depape, 1922 \\
\hline & $\begin{array}{l}\text { NW South America (Guasca } \\
\text { Valley formation, Colombia) }\end{array}$ & Hesperomeles & $\begin{array}{l}\text { Wijninga \& Kuhry, } \\
1993\end{array}$ \\
\hline
\end{tabular}


because there are many instances of convergence between their leaves and those of other families (Manchester, 1999).

The aim of the present work is to integrate phytogeographical, morphological and anatomical data and DNA results in order to elucidate intergeneric relationships within the subfamily Maloideae and to explain its current geographical distribution.

\section{MATERIAL AND METHODS}

Pomes of all genera of subfam. Maloideae were collected in Sir Harold Hillier Gardens and Arboretum, Royal Botanic Gardens at Kew, Wakehurst Gardens, University of Liverpool Botanic Gardens at Ness, Jardim Botânico da Madeira, and Real Jardín Botánico de Madrid and preserved in Kew mixture (Forman \& Bridson, 1989) (Appendix). Seeds were cut with a razor blade both longitudinally and transversely in order to examine their internal structure. Transverse sections were taken at one third of the length of the pome from the bottom and photographed by optical microscopy. Other sections were made with a SLEE-MAINZ-MTC microtome and stained with Fasga mixture (Tolivia \& Tolivia, 1987), a dye consisting of Safranin plus Alcyan green 2GX (Gurr Chemical Co.). Hence, the various plant structures were stained in different colours: cellulose walls in blue, sclerenchyma in pink, suberin in red, and tannins usually in reddish. Because malachite green stains cellulose walls (Alexander, 1980) it was used in some cuts to contrast sclereids against other parenchymatic cells. For scanning microscopy, seeds were sectioned with a microtome, glued on aluminium stubs, coated with 40-50 nm gold, and examined in a JEOL-TSM T330A scanning electron microscope (SEM) at $20 \mathrm{kV}$.

Table 3. Characters and character states.

1. Leaf persistence: $0=$ deciduous; $1=$ evergreen or semi-evergreen.

2. Stamen number: $0=$ lower than $30 ; 1=$ higher than 40 .

3. Number and arrangement of ovules in the carpel: $0=2$ collateral ovules per carpel; $1=2$ superposed ovules per carpel; $2=1$ ovule per carpel; $3=3$ or more ovules collateral and superposed forming columns in each carpel.

4. Style manner of emergence from ovary: $0=$ without a pit surrounding the style group; $1=$ with a pit surrounding the style group.

5. Fruit in pome: $0=$ absent; $1=$ present.

6. Sclereid features: $0=$ isolated sclereids; $1=$ small groups; $2=$ large and irregular groups; $3=$ large and rounded groups.

7. Pyrene presence and arrangement: $0=$ without pyrene; $1=$ Cotoneaster -type pyrene; $2=\mathrm{Cra}$ taegus-type pyrene; 3 = solitary pyrene.

8. False locular septa: $0=$ absent; $1=$ present.

9. Seed section: $0=$ flattened; $1=$ widely elliptic.

10. Ratio seed width/fruit width: $0=$ seeds occupying less than one half of fruit width; $1=$ seeds occupying more than one half of fruit width.

11. Seed shape: $0=$ oval or rounded seeds in a indehiscent pome; $1=$ winged seeds, in a dehiscent fruit.

12. Presence of endosperm: $0=$ present; $1=$ absent.

13. Number of endosperm layers: $0=2-4$ layers; $1=$ more than 5 layers.

14. Seed coat width: $0=1$ or 2 layers; $1=$ more than 3 layers.

15. Presence of Phloridzin: $0=$ absent; $1=$ present.

16. Chromosome number: $0=\mathrm{x} \neq 17 ; 1=\mathrm{x}=17$. 
Table 4. Character matrix used of Rosaceae subfam. Maloideae with Kageneckia and Vauquelinia as outgroups. Polymorphic data are coded as ' 0,1 '. See Table 3 for a list of characters and character states.

\begin{tabular}{lllllllllllllllll}
\hline & 1 & 2 & 3 & 4 & 5 & 6 & 7 & 8 & 9 & 10 & 11 & 12 & 13 & 14 & 15 & 16 \\
\hline Kageneckia & 1 & 0 & 3 & 0 & 0 & 0 & 0 & 0 & 0 & 0 & 1 & 0 & 0 & 0 & 0 & 1 \\
Vauquelinia & 1 & 0 & 0 & 0 & 0 & 0 & 0 & 0 & 0 & 0 & 1 & 0 & 0 & 0 & 0 & 0 \\
Amelanchier & 0 & 0 & 0 & 0 & 1 & 1 & 0 & 1 & 0 & 0 & 0 & 0 & 0 & 1 & 0 & 1 \\
Chaenomeles & 0 & 1 & 3 & 0 & 1 & 1 & 0 & 0 & 0 & 1 & 0 & 0 & 0 & 1 & 0 & 1 \\
Chamaemeles & 1 & 0 & 0 & 0 & 1 & 1 & 3 & 0 & 0 & 1 & 0 & 0 & 0 & 1 & 0 & 1 \\
Cotoneaster & $(0,1)$ & 0 & 0 & 0 & 1 & 1 & 1 & 0 & 0 & 1 & 0 & 0 & 0 & 0 & 0 & 1 \\
Crataegus & 0 & 0 & 1 & 0 & 1 & 1 & 2 & 0 & 0 & 1 & 0 & 0 & 1 & 0 & 0 & 1 \\
Cydonia & 0 & 0 & 3 & 1 & 1 & 2 & 0 & 0 & 0 & 1 & 0 & 0 & 0 & 1 & 0 & 1 \\
Dichotomanthes & 1 & 0 & 0 & 0 & 1 & 1 & 3 & 0 & 0 & 1 & 0 & 0 & 0 & 1 & 0 & 1 \\
Docynia & 1 & 1 & 3 & 0 & 1 & 1 & 0 & 0 & 0 & 1 & 0 & 0 & 0 & 1 & 1 & 1 \\
Eriobotrya & 1 & 0 & 0 & 0 & 1 & 0 & 0 & 0 & 1 & 0 & 0 & 1 & 0 & 1 & 0 & 1 \\
Hesperomeles & 1 & 0 & $(1,2)$ & 0 & 1 & 1 & 2 & 0 & 0 & 1 & 0 & 0 & 1 & 0 & 0 & 1 \\
Heteromeles & 1 & 0 & 0 & 0 & 1 & 1 & 0 & 0 & 0 & 1 & 0 & 0 & 0 & 1 & 0 & 1 \\
Malacomeles & 1 & 0 & 0 & 0 & 1 & 1 & 0 & 1 & 0 & 0 & 0 & 0 & 0 & 1 & 0 & 1 \\
Malus & 0 & 0 & 0 & 0 & 1 & 1 & 0 & 0 & 0 & 1 & 0 & 0 & 0 & 1 & 1 & 1 \\
Malus sect. Docyniopsis & 0 & 1 & 0 & 0 & 1 & 1 & 0 & 0 & 0 & 1 & 0 & 0 & 0 & 1 & 1 & 1 \\
Mespilus & 0 & 0 & 1 & 0 & 1 & 1 & 2 & 0 & 0 & 1 & 0 & 0 & 1 & 0 & 0 & 1 \\
Osteomeles & 1 & 0 & 2 & 0 & 1 & 1 & 2 & 0 & 0 & 1 & 0 & 0 & 1 & 0 & 0 & 1 \\
Peraphyllum & 0 & 0 & 0 & 0 & 1 & 1 & 0 & 1 & 0 & 0 & 0 & 0 & 0 & 1 & 0 & 1 \\
Photinia & $(0,1)$ & 0 & 0 & 0 & 1 & 1 & 0 & 0 & 0 & 1 & 0 & 0 & 0 & 1 & 0 & 1 \\
Pseudocydonia & 0 & 0 & 3 & 0 & 1 & 2 & 0 & 0 & 0 & 1 & 0 & 0 & 0 & 1 & 0 & 1 \\
Pyracantha & 1 & 0 & 0 & 0 & 1 & 1 & 1 & 0 & 0 & 1 & 0 & 0 & 0 & 0 & 0 & 1 \\
Pyrus & 0 & 0 & 0 & 1 & 1 & 2 & 0 & 0 & 0 & 1 & 0 & 0 & 0 & 1 & 0 & 1 \\
Rhaphiolepis & 1 & 0 & 0 & 0 & 1 & 0 & 0 & 0 & 1 & 0 & 0 & 1 & 0 & 1 & 0 & 1 \\
Sorbus subg. Sorbus & 0 & 0 & 0 & 0 & 1 & 1 & 0 & 0 & 0 & 1 & 0 & 0 & 0 & 1 & 0 & 1 \\
Sorbus subg. Aria & 0 & 0 & $(0,1)$ & 0 & 1 & 3 & 0 & 0 & 0 & 1 & 0 & 0 & 0 & 1 & 0 & 1 \\
Sorbus subg. Cormus & 0 & 0 & 0 & 0 & 1 & 3 & 0 & 0 & 0 & 1 & 0 & 0 & 0 & 1 & 0 & 1 \\
Sorbus subg. Torminaria & 0 & 0 & 0 & 0 & 1 & 1 & 0 & 0 & 0 & 1 & 0 & 0 & 0 & 1 & 0 & 1 \\
\hline
\end{tabular}

Sixteen morphological, anatomical and chemical characters (Table $3 \& 4$ ) were used in the cladistic analysis. Characters were compiled from literature or based on author's observations of herbarium and living material. A description of character and character states are presented in the Results section. Several other characters were tested but they were finally excluded due to high homoplasy indexes (HI higher than 0.625 ) or because they are continuous and do not present any clear gap.

Cladistic analyses were carried out using the software package PAUP 4.0 beta (Swofford, 1998). All characters were unweighted and unordered, data were analyzed and trees were constructed by using heuristic search. Polarization of characters into plesiomorphic and apomorphic states was assessed by using the outgroup comparison (Watrous \& Wheeler, 1981). MacClade version 3.04 (Maddison \& Maddison, 1992) was used to edit the data set analyzed by PAUP, as well as to map the distribution of particular character state changes. Furthermore, a bootstrap analysis was conducted (Felsenstein, 1985).

In the present work, Vauquelinia and Kageneckia were selected as outgroups. They were generally considered as related to Maloideae because similarities in the 
configuration of ovary, fusion of carpels and floral vascularization (Sterling, 1965a, b, c, 1966; Evans \& Dickinson, 1999). This relation was also suggested by Campbell et al. (1995) and Evans \& Campbell (2002) after studying the ITS and GBSSI sequences. According to Kalkman (1988) Vauquelinia belongs to a clade including Osmaronieae, Pruneae, Kerrieae, and Quillajeae (Exochorda Lindl., Lindleya Kunth and Vauquelinia) which is considered as sister group of Maloideae. Phipps et al. (1991) considered Vauquelinia as "typically spiraeoid except in number and winged seeds". Other authors preferred to include Vauquelinia and Kageneckia in Maloideae (Goldblatt, 1976; Morgan et al., 1994; Takhtajan, 1997).

To determine distribution areas which were most similar based on the occurrence of genera, we compared the regions pairwise, with respect to presence or absence of genera (Holloway \& Jardine, 1968; Hengeveld, 1990). The biogeographic system by Takhtajan (1986) was used for this comparison. A matrix of biogeographical regions versus taxa (presence or absence) was made and the regions were compared by using the index by Kulczynski (1928). This index is appropriate for examination of general biotic similarity based on the number of shared taxa. The matrix was then used to carry out a non-metric multi-dimensional scaling analysis (NMS), assessing the goodness of fit for the resulting spatial configurations through stress values (Kruskal \& Wish, 1978). In order to interpret the plot, a minimum spanning tree (MST) was superposed upon the vectors to detect any undue distortion imposed on multidimensional configuration of regions (Dunn \& Everitt, 1982). Finally, this tree was superposed on the map of biogeographic regions (Takhtajan, 1986). NMS analysis was carried out by using the NTSYS-pc 1.7 package (Rohlf, 1992).

Previously the areas of endemism were defined. An area of endemism is a geographic region to which one or more taxa are confined (Axelius, 1991). Using current methods to identify areas of endemism, we have defined 8 areas: a) Central Asia, West Asia, Europe, North Africa; b) South East Asia; c) East Pacific islands; d) Caucasus, Anatolia; e) Macaronesia; f) West North America; g) Central and South America; h) East North America. Most of these areas have endemic genera, but in some cases genera are shared by two areas, i.e., Osteomeles in b and c, or Cormus in a and d.

\section{RESULTS}

\section{Character selection, definition and coding}

The characters used in the analysis are listed in Table 3 and 5 and discussed below. Many characters were evaluated but excluded as uninformative at this level of analysis for being either autapomorphic or too variable within genera.

Character 1: Leaf persistence. According to Phipps et al. (1991) this character could be codified in the following states: $0=$ deciduous, $1=$ wintergreen, $2=$ evergreen . However, we preferred to simplify it using only two character states (deciduous and evergreen or semi-evergreen).

Character 2: Stamen number. Phipps et al. (1991) considered lower numbers as primitive and higher as derived and codified this character in four states. We have simplified this character into two states with a clear gap: lower than 30, which is considered as primitive and higher than 40 (in Chaenomeles, Docynia and Malus sect. Docyniopsis) which is considered as derived. The most frequent number in 
Maloideae c. 20, is also the number reported in Vauquelinia (18-20 according to Hess \& Henrickson, 1987). Fewer than 10 stamens is only reported in Crataegus macrosperma (Rohrer et al., 1994).

Character 3: Number and arrangement of ovules. In subfamily Maloideae each carpel includes generally two ovules except for Osteomeles and some Hesperomeles, which have only one per carpel, and Chaenomeles, Cydonia, Docynia and Pseudocydonia which have more than three. Phipps et al. (1991) considered lower numbers as more primitive, codifying them from 1 to 4 . However, we think that both numbers: lower and higher than two should be considered as derived.

In Vauquelinia and most Maloideae the ovule arrangement is collateral which can be considered as the primitive condition. It is superposed in Crataegus, Mespilus, and some species of Hesperomeles and Sorbus subg. Aria. Most Hesperomeles species have a solitary ovule per carpel but Hesperomeles oblonga Lindl. has two superposed ovules per carpel (Sterling, 1964). We also have found many Sorbus species, mainly from East Asia, which have superposed ovules (see also the drawings of S. corymbifera (Miq.) Tiep \& Yakovlev by Kalkman (1973) and of S. caloneura by Stapf (1910)). The genera with more than 3 ovules per carpel (Chaenomeles, Cydonia, Docynia, Pseudocydonia) show both types of arrangement: collateral and superposed, and they usually have several columns of ovules in each carpel. In Docynia they are superposed in 1 or 2 columns of ovules. Also Kageneckia shows multiple ovules disposed in both types of arrangement. We propose that the state of two collateral ovules could have evolved into the other three states mentioned: one solitary ovule, two superposed ovules and more than three ovules.

Character 4: Style manner of emergence from ovary. The presence of a pit in the floral cup surrounding the style group is shared by Cydonia and Pyrus, while all the other taxa and the outgroup do not have this structure; consequently the presence of this pit should be considered as a derived state of character (Aldasoro et al., 1998a). Other Maloideae have styles which emerge fused or independently from the top of the ovary. The grade of style fusion varies frequently even within each genus and it was not useful in this analysis. Dichotomanthes has a remarkable autapomorphy, namely the style emerging laterally from the base of the carpel (Gladkova, 1969).

Character 5: Fruit types. The fleshy fruit formed by fusion of parts of hypanthium and carpels is a shared feature of Maloideae and is usually called pome. Dichotomanthes has a rather distinctive fruit with a fleshy hypanthium which covers the only hard carpel (pyrene) but both hypanthium and pyrene are independent. This special fruit is generally considered as an early pome (Rohrer et al., 1994). Moreover, in Dichotomanthes sclereid shape and stiffness are very similar to those with hard Crataegus-type pyrenes (data not shown). Dichotomanthes wood anatomy (Zhang \& Baas, 1992) and flavonoid chemistry (Challice \& Kovanda, 1981) are also similar to other Maloideae. Consequently, we preferred to consider the fruit of Dichotomanthes as a pome. On the other hand, all the Spiraeoideae have dry fruits: capsules, achenes or follicules.

Character 6: Sclereid features. Four main sclereid arrangement types could be distinguished in the flesh of Maloideae pomes: most of sclereids isolated, with some sparse small groups, as in Eriobotrya and Rhaphiolepis; all sclereids forming small groups (less than 10 sclereids), as in Malus, Photinia and Sorbus subg. Sorbus; large but 
Table 5. Features of flower, pome and seed in Maloideae genera; $*$ indicates data which were taken from Robertson et al. (1991) and ** from Decaisne (1874); those data were all corroborated and the rest were obtained during the present study.

\begin{tabular}{|c|c|c|c|c|c|}
\hline Genus & Leaf & Flower & & & Pome \\
\hline & $e^{\frac{2}{2}}$ & 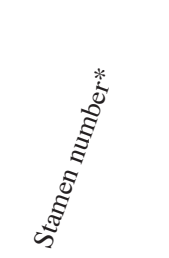 & 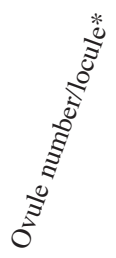 & 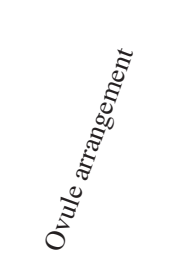 & $\underbrace{*}_{2}$ \\
\hline Kageneckia & evergreen & $18-20$ & $>10$ & $\begin{array}{l}\text { collateral and } \\
\text { superposed }\end{array}$ & $\begin{array}{l}\text { absent (achene } \\
\text { internally sclerified) }\end{array}$ \\
\hline Vauquelinia & evergreen & $18-20$ & 2 & collateral & $\begin{array}{l}\text { absent (achene } \\
\text { internally sclerified) }\end{array}$ \\
\hline Amelanchier & deciduous & 20 & 2 & collateral & absent \\
\hline Chaenomeles & deciduous & $40-55$ & $>10$ & $\begin{array}{l}\text { collateral and } \\
\text { superposed }\end{array}$ & absent \\
\hline Chamaemeles & evergreen & $10-15$ & 2 & collateral & single \\
\hline Cotoneaster & $\begin{array}{l}\text { deciduous or } \\
\text { evergreen }\end{array}$ & $10-20$ & 2 & collateral & contiguous \\
\hline Crataegus & deciduous & $5-20$ & 2 & superposed & separated by flesh \\
\hline Cydonia & deciduous & 25 & $>10$ & $\begin{array}{c}\text { collateral and } \\
\text { superposed }\end{array}$ & absent \\
\hline Dichotomanthes & evergreen & 20 & 2 & collateral & single \\
\hline Docynia & $\begin{array}{l}\text { evergreen or } \\
\text { semi-evergreen }\end{array}$ & 40 & $3-10$ & $\begin{array}{l}\text { both positions, } \\
\text { collateral and } \\
\text { superposed }\end{array}$ & absent \\
\hline Eriobotrya & evergreen & $15-25$ & 2 & collateral & absent \\
\hline Hesperomeles & evergreen & 20 & 1,2 & superposed & separated by flesh \\
\hline Heteromeles & evergreen & 10 & 2 & collateral & absent \\
\hline Malacomeles & evergreen & $10-20$ & 2 & collateral & absent \\
\hline Malus & $\begin{array}{l}\text { deciduous, } \\
\text { evergreen or } \\
\text { semi-evergreen }\end{array}$ & $\begin{array}{l}15-30 \text { (in sect. } \\
\text { Docyniopsis } \\
\text { up to } 55 \text { ) }\end{array}$ & 2 & collateral & absent \\
\hline Mespilus & deciduous & $20-30$ & 2 & superposed & separated by flesh \\
\hline Osteomeles & evergreen & $20-25$ & 1 & - & separated by flesh \\
\hline Peraphyllum & deciduous & 20 & 2 & collateral & absent \\
\hline Photinia & $\begin{array}{l}\text { deciduous, } \\
\text { evergreen or } \\
\text { semi-evergreen }\end{array}$ & 20 & 2 & collateral & absent \\
\hline Pseudocydonia & deciduous & 20 & $>10$ & $\begin{array}{l}\text { collateral and } \\
\text { superposed }\end{array}$ & absent \\
\hline Pyracantha & evergreen & $15-20$ & 2 & collateral & contiguous \\
\hline Pyrus & deciduous & $15-30$ & 2 & collateral & absent \\
\hline Rhaphiolepis & evergreen & $15-20$ & 2 & collateral & absent \\
\hline \multicolumn{6}{|l|}{ Sorbus } \\
\hline subg. Aria & deciduous & 20 & 2 & $\begin{array}{l}\text { some superposed, } \\
\text { other collateral }\end{array}$ & absent \\
\hline subg. Cormus & deciduous & 20 & 2 & collateral & absent \\
\hline subg. Sorbus & deciduous & 20 & 2 & collateral & absent \\
\hline subg. Torminaria & deciduous & 20 & 2 & collateral & absent \\
\hline
\end{tabular}


Table 5 (continued)

\begin{tabular}{|c|c|c|c|c|c|c|c|}
\hline Pome (cont.) & & Seed & & & & & \\
\hline 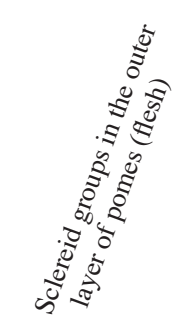 & 这 & 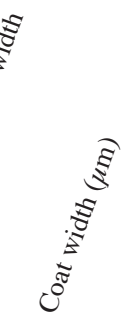 & 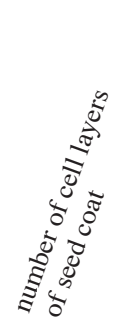 & 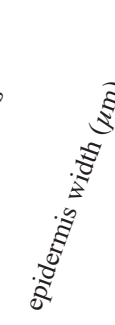 & & 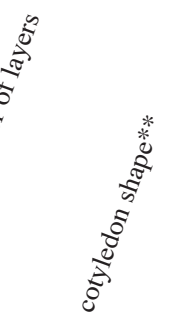 & 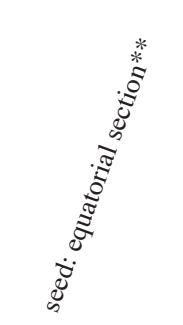 \\
\hline solitary or small & $0.5-0.7$ & $14-18$ & 2,3 & $20-30$ & $2-4$ & hemi-ellipsoidal & $\begin{array}{l}\text { narrowly elliptic } \\
\text { and winged }\end{array}$ \\
\hline solitary or small & $0.5-0.7$ & $14-16$ & 1,2 & $20-30$ & 2,3 & hemi-ellipsoidal & $\begin{array}{l}\text { narrowly elliptic } \\
\text { and winged }\end{array}$ \\
\hline small & $0.5-0.7$ & 100 & 4,5 & $0-20$ & 3,4 & hemi-ellipsoidal & elliptic \\
\hline small & $0.1-0.2$ & 140 & 8 & 20 & 3,4 & hemi-ellipsoidal & elliptic \\
\hline small & $0.2-0.4$ & $50-58$ & $3-5$ & $10-12$ & 3,4 & spirally folded & elliptic \\
\hline small & $0.4-0.5$ & $10-15$ & 1,2 & $20-30$ & 4,5 & hemi-ellipsoidal & elliptic \\
\hline small & $0.2-0.5$ & $23-30$ & $1-3$ & $15-20$ & $5-16$ & hemi-ellipsoidal & elliptic \\
\hline great irregular & $0.1-0.2$ & 130 & 5 & $60-90$ & $2-4$ & hemi-ellipsoidal & elliptic \\
\hline small & $0.4-0.5$ & $28-32$ & 3,4 & $20-25$ & 2,3 & hemi-ellipsoidal & elliptic \\
\hline small & 0.29 & 150 & 6 & $50-70$ & 3 & hemi-ellipsoidal & elliptic \\
\hline solitary or small & $0.7-0.9$ & $200-400$ & $15-18$ & $0-25$ & 0 & hemisphaeric & $\begin{array}{l}\text { rounded or } \\
\text { widely elliptic }\end{array}$ \\
\hline small & $0.3-0.4$ & $10-20$ & 1,2 & $10-15$ & $7-15$ & hemi-ellipsoidal & elliptic \\
\hline small & $0.28-0.31$ & $60-65$ & 3,4 & $35-40$ & 3 & hemi-ellipsoidal & elliptic \\
\hline small & $0.5-0.7$ & 100 & 4,5 & 80 & 3,4 & hemi-ellipsoidal & elliptic \\
\hline small & $0.3-0.5$ & $60-110$ & 3,4 & $18-70$ & 3,4 & hemi-ellipsoidal & elliptic \\
\hline small & 0.28 & 10 & 1,2 & 10 & $9-13$ & hemi-ellipsoidal & elliptic \\
\hline small & $0.3-0.5$ & $30-60$ & 1,2 & $40-50$ & 6,7 & hemi-ellipsoidal & elliptic \\
\hline small & $0.5-0.7$ & 240 & 10 & - & 3,4 & hemi-ellipsoidal & elliptic \\
\hline small & $0.19-0.46$ & $35-110$ & $3-5$ & $8-50$ & 3,4 & hemi-ellipsoidal & elliptic \\
\hline great irregular & $0.1-1.2$ & 120 & 4,5 & 20 & 3,4 & hemi-ellipsoidal & elliptic \\
\hline small & $0.3-0.5$ & $8-16$ & 1,2 & $10-15$ & 3,4 & hemi-ellipsoidal & elliptic \\
\hline great irregular & $0.2-0.4$ & $120-170$ & $7-10$ & $50-60$ & $2-4$ & hemi-ellipsoidal & elliptic \\
\hline solitary or small & $0.7-0.9$ & $100-250$ & $8-15$ & - & 0 & hemisphaeric & $\begin{array}{l}\text { rounded or } \\
\text { widely elliptic }\end{array}$ \\
\hline large rounded & $0.2-0.5$ & $85-200$ & $3-7$ & $0-25$ & 3,4 & hemi-ellipsoidal & $\begin{array}{l}\text { elliptic or } \\
\text { narrowly elliptic }\end{array}$ \\
\hline large rounded & 0.3 & 150 & 5,6 & 10 & 3 & hemi-ellipsoidal & narrowly elliptic \\
\hline small & $0.2-0.4$ & $50-180$ & $3-5$ & $14-30$ & 4,5 & hemi-ellipsoidal & elliptic \\
\hline small & 0.44 & $100-240$ & $4-6$ & 30 & 3 & hemi-ellipsoidal & elliptic \\
\hline
\end{tabular}




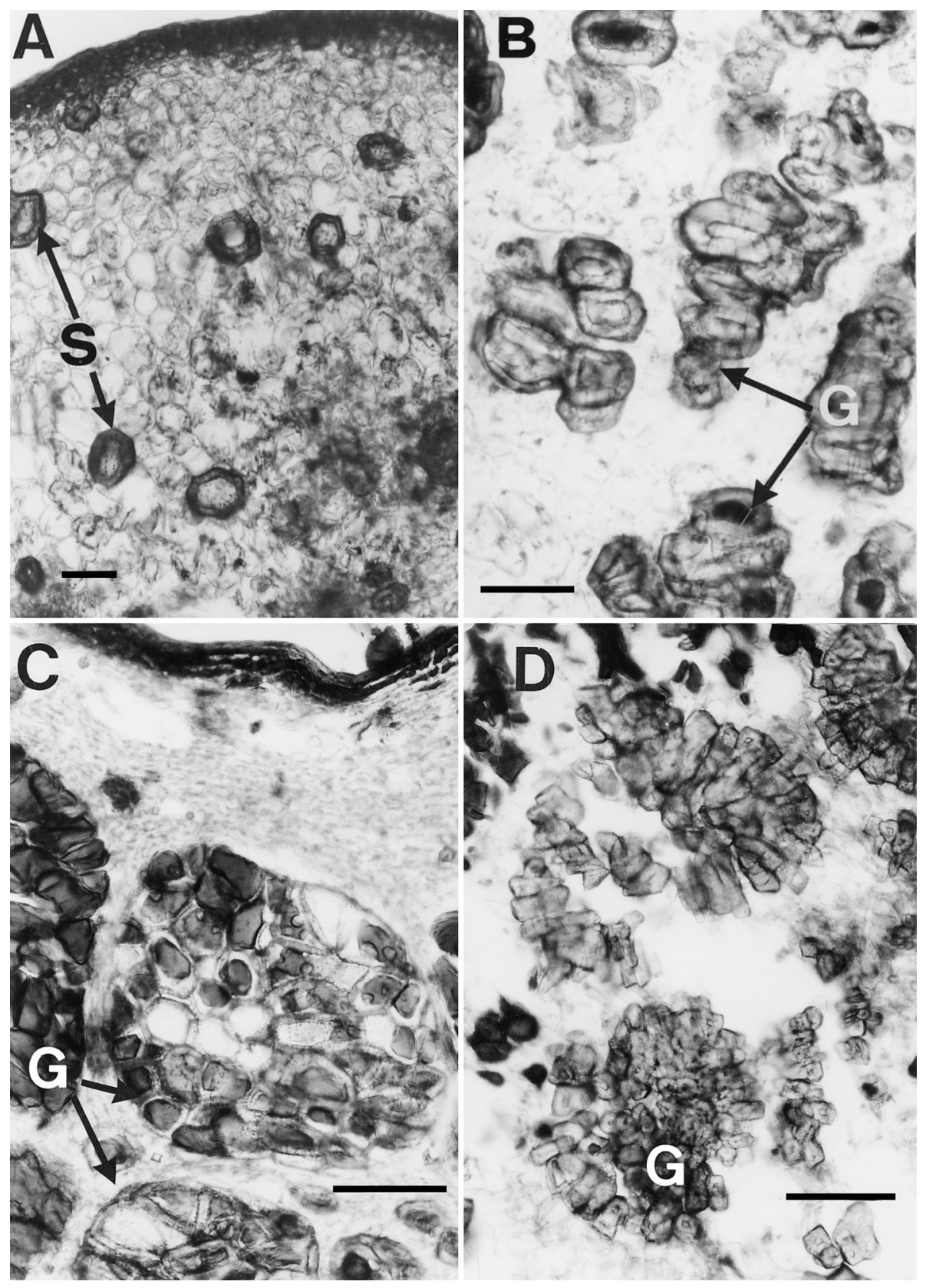

Fig. 1. Optical microphotographs of transverse cuts made of the pome flesh showing four types of sclereid arrangement. - A. Eriobotrya benghalensis (Aldasoro 717): isolated sclereids (S). B. Malus tschonoskii (Aldasoro 643): small groups of sclereids (G). - C. Sorbus lanata (Aldasoro 624): rounded groups of sclereids (G). - D. Pyrus syriaca (Aldasoro 668): irregular groups of sclereids (G). Scale bars: A, B $=50 \mu \mathrm{m} ; \mathrm{C}=100 \mu \mathrm{m} ; \mathrm{D}=200 \mu \mathrm{m}$. 
irregular groups, as in Cydonia, Pyrus and Pseudocydonia, and large and rounded groups, as in Sorbus subgenera Aria and Cormus (Fig. 1) (Aldasoro et al., 1998b). Vauquelinia and Kageneckia have small solitary sclereids more or less spread in the outer part of the pome and crowded sclereids in something similar to a pyrene in the inner part.

Isolated sclereids could evolve in several types of groups during the development of the subfamily: 1) small groups; 2) large and rounded groups showing a broad lumen; 3) large and irregular groups showing a small lumen with large walls; these states seem to be derived (Aldasoro et al., 1998a, b).

Character 7: Pyrene arrangement. Pulp structure in Maloideae may have been developed through the loss of sclerenchymatous cells (fleshy pomes) or through a specialized distributional pattern of sclerenchymatous cells (pyrene pomes), according to observations of Iketani \& Ohashi (1991). The plesiomorphic condition seems to be a dry achene internally sclerified as in Vauquelinia. Three types of pyrenes could be distinguished in Maloideae (Phipps et al., 1991): 1) the Cotoneaster-type, with contiguous pyrenes, not separated by flesh (Cotoneaster and Pyracantha) (Fig. 2; Table 4); 2) the Crataegus-type with flesh separating the pyrenes (Crataegus, Mespilus, Osteomeles and Hesperomeles); 3) the solitary pyrene of Dichotomanthes and Chamaemeles. The remaining taxa of the subfamily have pomes without pyrenes. We found a layer of collapsed sclereids similar to an incipient pyrene surrounding the seeds of several Malus species. These layers were separated by flesh, as in the Crataegus-type pyrene. Phipps et al. (1991) suggested that the very hard pyrenes of the Crataegus-type have been derived from an hardening core like that of Malus, rather than a soft pyrene like Pyracantha and Cotoneaster.

Character 8: False locular septa. False septa partially divide locules in Amelanchier, Malacomeles and Peraphyllum (Rohrer et al., 1994). We have also simplified this character into two states (Phipps et al., 1991).

Character 9: Seed section. The outgroup and most of Maloideae have seeds with more or less flattened, elliptic equatorial sections, while Eriobotrya and Rhaphiolepis have a rounded or widely elliptic section. This characteristic seems to be meaning for
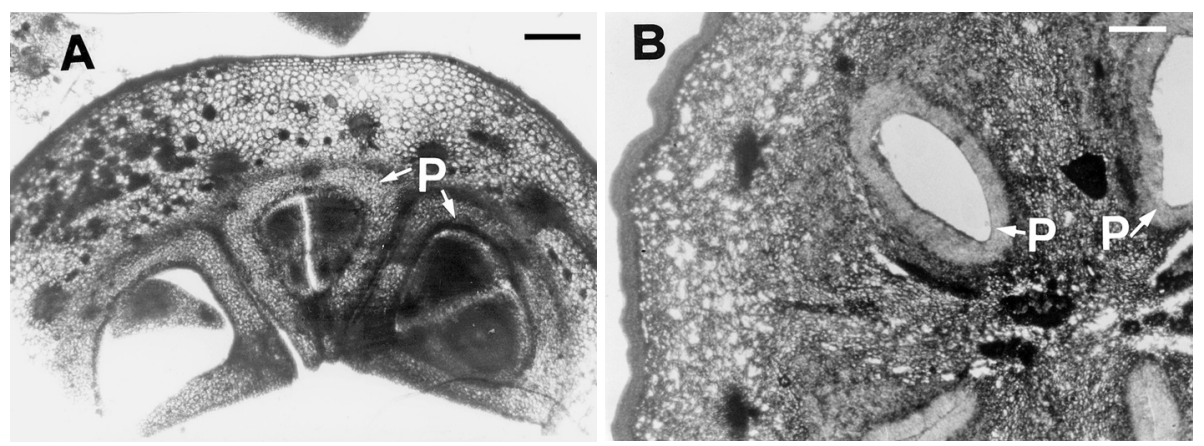

Fig. 2. Optical microphotographs of transverse cuts made of the pome showing pyrene types. A. Pyracantha crenatoserrata (Aldasoro 727): connate pyrenes (P). - B. Crataegus pentagyna (Aldasoro 682): pyrenes separated by flesh $(\mathrm{P})$. Scale bars $=0.5 \mathrm{~mm}$. 

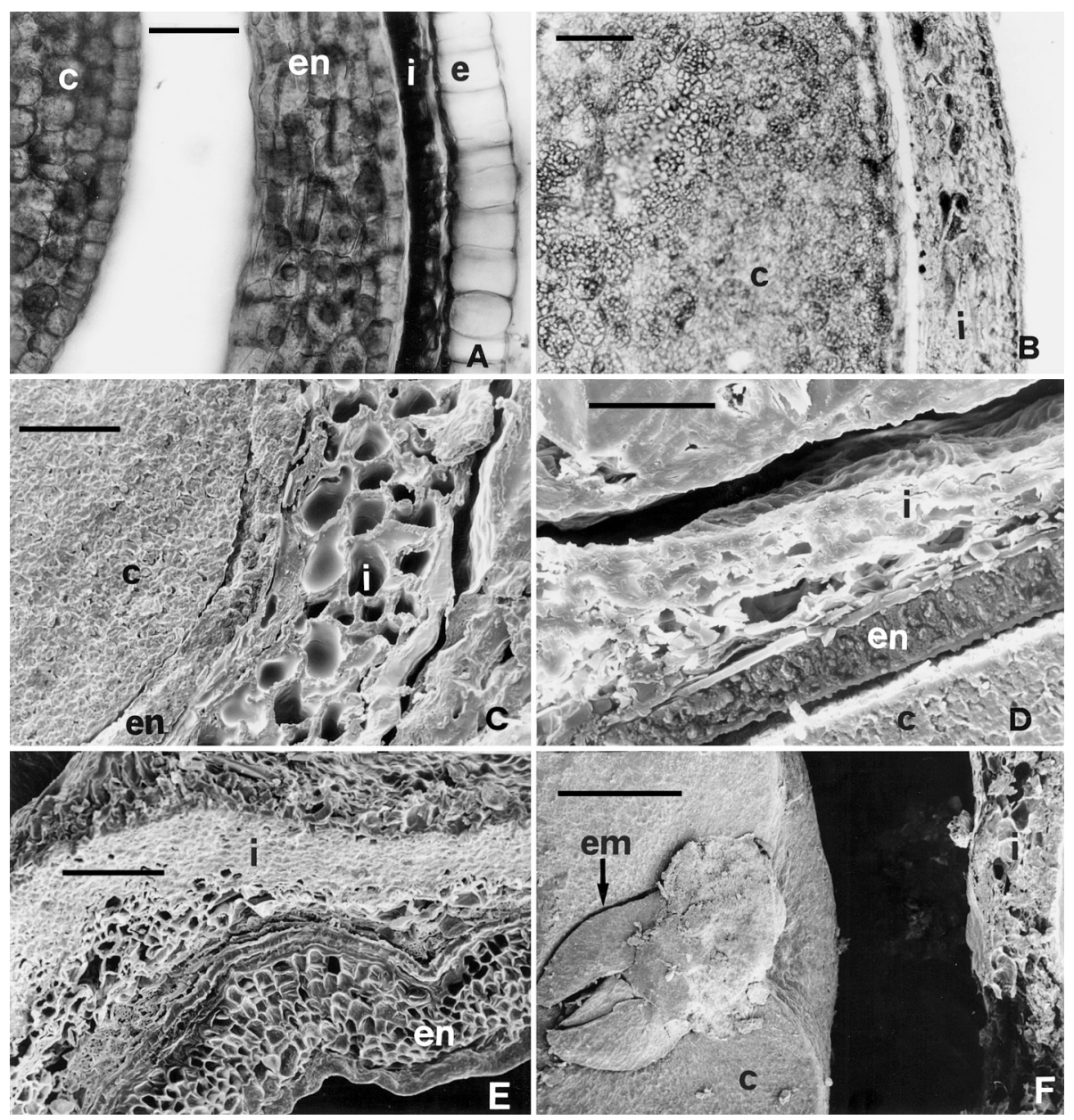

Fig. 3. Optical (A, B) and SEM (C-F) microphotographs of transverse cuts of seeds of subfam. Maloideae. - A. Crataegus oresbia (Aldasoro 689). - B. Rhaphiolepis indica (Aldasoro 713), endosperm absent. - C. Photinia melanocarpa (Aldasoro 710). - D. Sorbus hemsleyi (Aldasoro 699). - E. Pyrus pashia (Aldasoro 641). - F. Rhaphiolepis indica (Aldasoro 713), endosperm absent. $-\mathrm{c}=$ cotyledons, $\mathrm{em}=$ embryonic axis, en $=$ endosperm, $\mathrm{e}=$ outer epidermis in palisade, $\mathrm{i}=$ integuments. Scale bars: $\mathrm{A}=25 \mu \mathrm{m} ; \mathrm{B}, \mathrm{C}, \mathrm{E}=100 \mu \mathrm{m} ; \mathrm{D}=50 \mu \mathrm{m} ; \mathrm{F}=500 \mu \mathrm{m}$.

both genera, and we have considered the latter state as derived. It is interesting that both genera have proportionally larger seeds than other Maloideae and inhabit tropical or subtropical evergreen forests of South Eastern Asia (Vidal, 1965; Kalkman, 1973). Larger seeds survive longer in forest understorey under reduced light intensity (Foster, 1986). Moreover, Eriobotrya cotyledons are photosynthetic, greening during germination (Ernst, 1906).

Character 10: Ratio seed width/pome width. Some genera have seeds occupying more than one half of pome width, as is the case in Amelanchier, Malacomeles, Peraphyllum, Eriobotrya and Rhaphiolepis. The remaining genera have smaller seeds, 
occupying less than a $40 \%$ of pome width. Fleshiness of fruits is generally related to the type of dissemination by animals. Fruit dispersed by mammals generally have more flesh (Herrera, 1989) and should became more important after the Middle Tertiary (Tiffney, 1984; Primack, 1987).

Character 11: Seed shape. Vauquelinia and Kageneckia, which are closely related to Maloideae, show winged seeds, associated to anemochory and similar to those of some other Spiraeoideae. The rest of the genera have oval or rounded seeds included in the pome.

Character 12: Presence of endosperm. All Eriobotrya and Rhaphiolepis seeds studied in this work showed no endosperm development (Fig. 3B, F). Seeds of other genera of subfam. Maloideae retained variable amounts of endosperm. According to Péchoutre (1902) the presence of endosperm is widespread in many groups of Rosaceae, varying from a single layer in Roseae, Pruneae and Spiraeae, to 15 in some Maloideae (Table 4). Hess \& Henrickson (1987) reported that seeds of Vauquelinia have no endosperm; however, we found in seeds of this genus 2 or 3 layers of endosperm cells.

Character 13: Number of endosperm layers. As it was previously mentioned, some genera of Maloideae have a more developed endosperm, as is the case in Crataegus, Hesperomeles, Mespilus and Osteomeles, which have the thickest endosperm consisting of more than 5 layers (Fig. 3A, Table 4). The endosperm of the remaining genera is generally 2-4 layers thick (Fig. 3C-E). Considering that the outgroups have 2 or 3 layers, some genera of Maloideae could have evolved towards an increase in the number of layers (Crataegus, Hesperomeles, Mespilus and Osteomeles), while others could loose it (Eriobotrya and Rhaphiolepis).

Character 14: Number of seed coat layers. The seed coat is most developed in Erio botrya and Rhaphiolepis seed, species showing 8-18 layers of cells (Table 4). Pyrus, Sorbus subg. Aria and subg. Torminaria seeds have testas with 3-10 cell layers. Some taxa with pyrenes such as Chamaemeles and Dichotomanthes have 3-5 layers, but in most of them (Cotoneaster, Crataegus, Mespilus, Osteomeles and Pyracantha) the testa has only 1 or 2 layers. Vauquelinia has a thin 1- or 2-layered testa with a conspicuous epidermis. A mucilaginous epidermis characterizes some species of Cydonia, Malacomeles, Malus sect. Eriolobus and Photinia, while in the other genera it was absent.

Character 15: Presence of Phloridzin (phloretin 2'-glucoside). Challice (1973) and Williams (1982) studied leaf phenolics in subfamily Maloideae reporting that the presence of this dihydrochalkone is a common feature in Docynia, Malus and Malus sect. Docyniopsis. Phloridzin is absent in the outgroups (Challice, 1974).

Character 16: Chromosome number. The basic chromosome number $\mathrm{x}=17$ is shared by some Spiraeoideae (Kageneckia and Lindleia) and all Maloideae, while Vauquelinia has $\mathrm{x}=15$.

\section{Cladistic analysis}

The cladistic analysis with equal weighting gave 702 minimal length cladograms, consisting of 35 steps, a consistency index (CI) of 0.771 , a retention index (RI) of 0.851 , a rescaled consistency index $(\mathrm{RC})$ of 0.657 , and a homoplasy index (HI) of 0.371 . The strict consensus tree is showed in Fig. 4. 
Strict

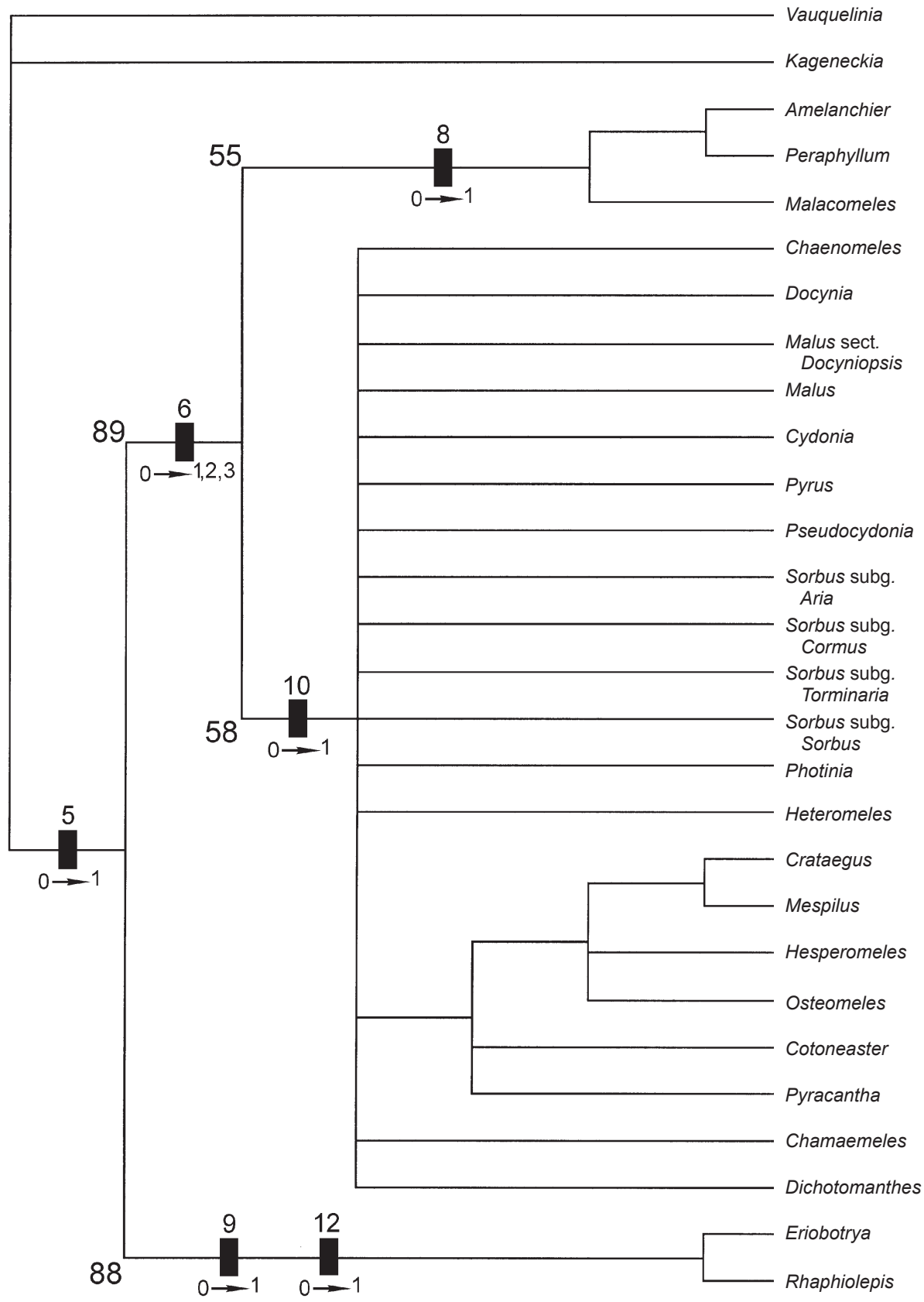

Fig. 4. Strict consensus of 702 most parsimonious trees based on the complete dataset. Number above branches indicates bootstrap values from 100 replicates. Solid bars are synapomorphies, above each bar the character number is shown and below are the changes suffered by its states; numbers beside the clades are bootstrap supports (only those higher than $50 \%$ are showed). 
The consensus tree is not fully resolved and there is considerable homoplasy. The consensus tree shows several weak clades which were not firmly supported by the bootstrap values (Fig. 4). However, several groupings are constant. The ingroup is supported by one synapomorphy: the fruit in pome (character 5), while the outgroups share the winged seeds (character 11). The chromosome number $\mathrm{x}=17$ is also shared by two Spiraeoideae: Lindleia and Kageneckia, and consequently it is not a synapomorphy of Maloideae.

In the tree showed in Fig. 4 there are two major groups: one formed by Eriobotrya and Rhaphiolepis and another including the remaining genera. The first clade has a high bootstrap support and has two synapomorphic characters (9 and 12), while the second clade is supported by only one (6). Characters 9 and 12 are: the presence of rounded or widely elliptic seeds, and the absence of endosperm, respectively. The loss of endosperm seems an important feature, until now not found in any of the studied Maloideae (Péchoutre, 1902; Danilova, 1996; Takhtajan, 1997).

The second clade, including all the remaining genera of Maloideae, has low bootstrap values and is supported only by the presence of groups of sclereids in the flesh (character 6). There is a minor clade in this group formed by Malacomeles, Peraphyllum and Amelanchier, genera which shared a synapomorphy: the false septa dividing the locules in each carpel (character 8). They have small pseudoberry pomes with sparse groups of sclereids and without any layer of collapsed sclereids protecting the seeds. The rest of the taxa are in a group supported by character 10: they have more fleshy pomes (measured by a lower ratio seed length/pome length). The relations within this clade have not been fully solved as shown in the strict consensus tree (Fig. 4). The only recognisable group in this clade is formed by the genera with Crataegus-type pyrenes.

\section{Analysis of regions}

The sixteen regions used for this study varied in taxon richness from one genus (i.e., Fiji, Hawaiian, Polynesian and Andean Regions) to fifteen genera from the Eastern Asiatic Region: seventeen, if all the taxa used in cladistic analysis are considered (Fig. 5). The areas of highest endemism were the Eastern Asiatic Region with Dichotomanthes and Pseudocydonia (Tsun-shen et al., 1993) and the Madrean with Heteromeles and Peraphyllum (Axelrod, 1958; Raven \& Axelrod, 1974). Malacomeles is almost endemic, living only in two regions: Madrean and Caribbean. Some other genera like Docynia have a very restricted distribution in the east of the Himalayas, extending in the limits of the Eastern Asiatic, Indochinese and Indian Regions (Browicz, 1969). Also Eriobotrya and Rhaphiolepis are restricted to the Eastern Asiatic, Indochinese, Malaysian and Indian Regions (Vidal, 1965). Another region with endemic genera is Macaronesia (with Chamaemeles). Two genera have disjunct distribution areas; they are: Osteomeles, which grows in East Asia and in many Pacific islands (Van Steenis \& Van Balgooy, 1966), and Photinia, which is present in North and Central America and East Asia (Table 6). Pyracantha and Pyrus have two separate nuclei in the Palearctic Region: one in East Asia and the other in Europe (Browicz, 1992). 53\% of Eastern Asiatic genera are evergreen while in the Indochinese and Malaysian Regions the percentages are $75 \%$ and $80 \%$, respectively. The proportion of evergreens decreased towards the west: in the Indian Region $71.4 \%$ while in the Irano-Turanian Region it 


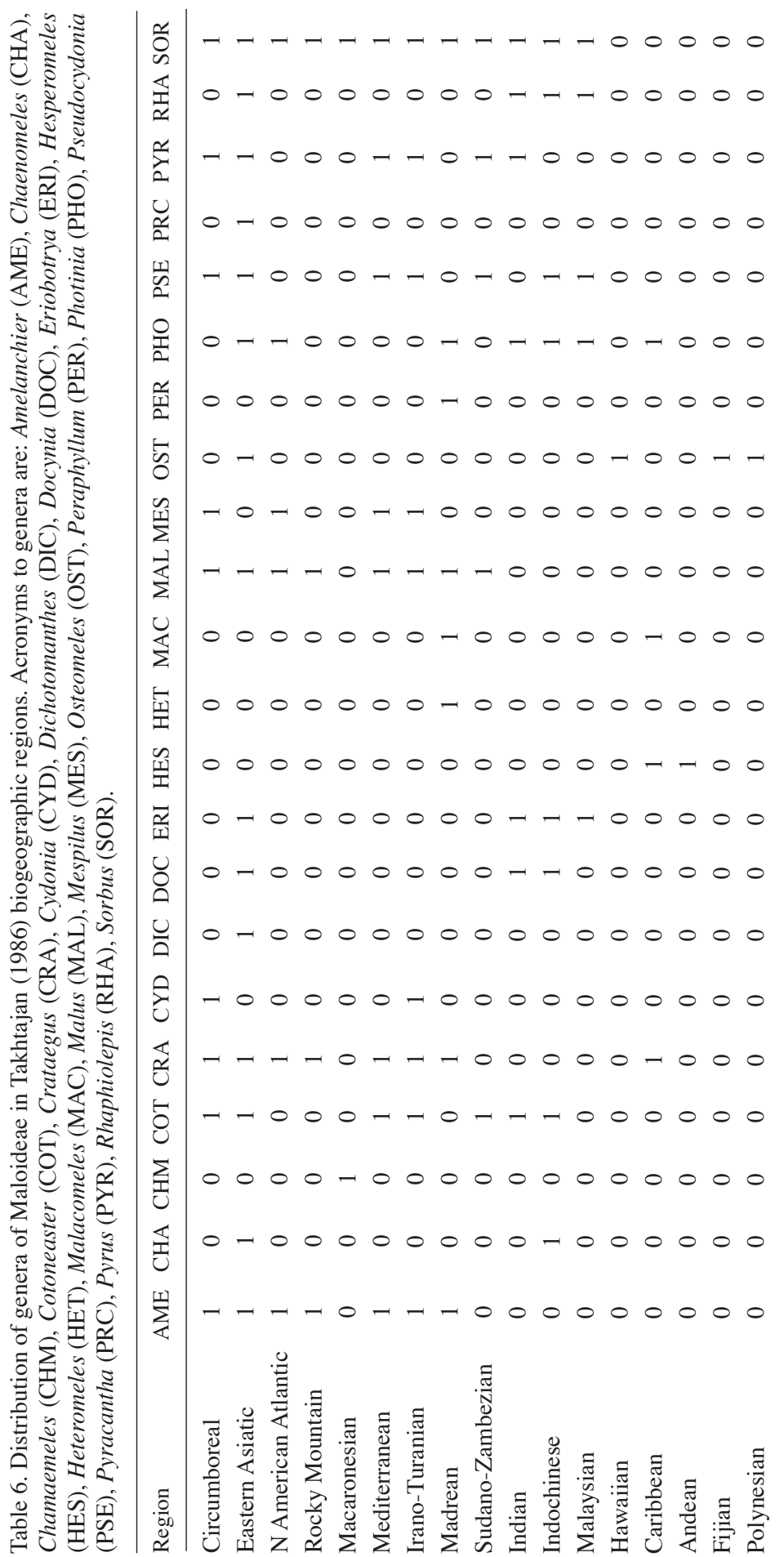




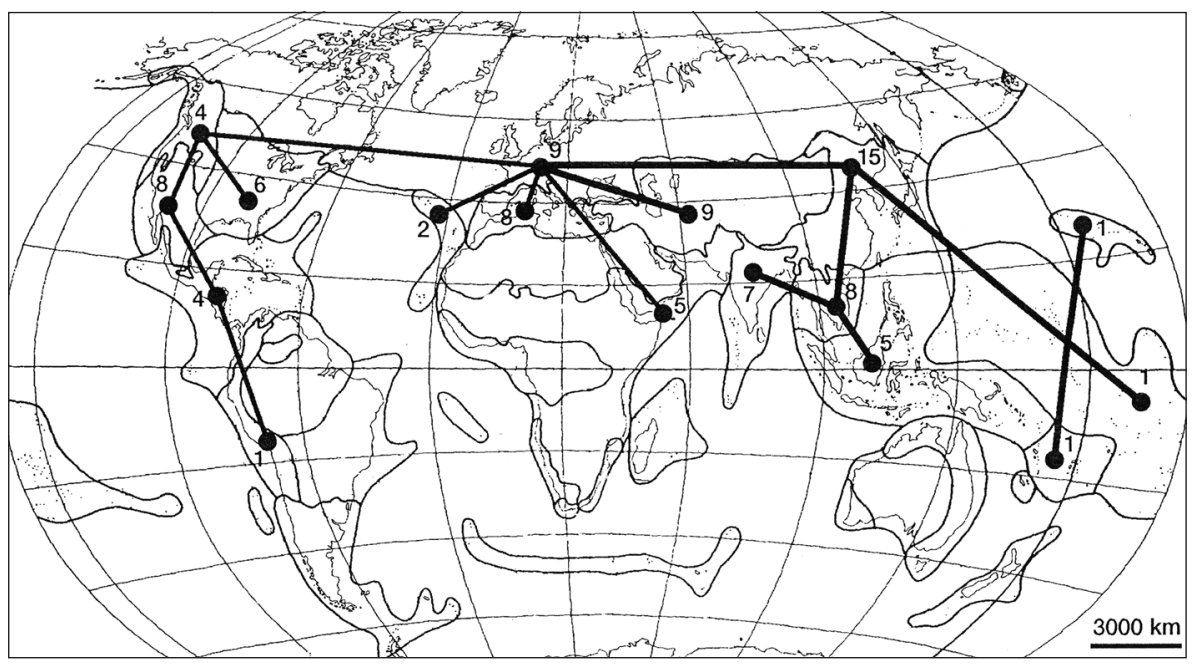

Fig. 5. Minimum Spanning Tree and Non-Metric Multidimensional Scaling (NMS) analysis superposed on a map showing Takhtajan biogeographic regions. Stress of NMS analysis was 0.169 . The number of genera growing in each region is also showed on the map.

diminished to $22 \%$. The highest rate of evergreens in North America is reached in the Madrean, Caribbean and Andean Regions.

While some genera have a very wide distribution (Holarctic) such as Amelanchier, Crataegus, Malus, Mespilus and Sorbus (only subg. Sorbus) (Browicz, 1971; Likhonos, 1974; Phipps, 1990; Phipps et al., 1990), Cotoneaster, Pyracantha, Pyrus and Sorbus (subg. Aria), are exclusively Palearctic (Phipps et al., 1990; Browicz, 1992; Aldasoro et al., 1996, 1998b).

The minimum spanning tree obtained from the analysis using multidimensional scaling showed a pattern of relationships among the biogeographical regions based on shared genera, and could indicate paths of migration of these genera (Fig. 5). The Eastern Asiatic Region showed three main links: 1) with Hawaiian, Polynesian and Fijian Regions (1 genus shared); 2) with Indian, Indochinese and Malaysian Regions (4 genera shared); and 3) with the Irano-Turanian ( 7 genera shared), Circumboreal (7 genera shared) and Mediterranean Regions ( 7 genera shared). The latter mentioned regions are related by the minimum spanning tree to the Rocky Mountains Region which is furthermore related to two areas, namely the North American Atlantic Region and the Madrean Region (related moreover to the Caribbean Region and finally to the Andean Region).

A high number of genera (15), many of them endemic, occur from southern to the south-east of China, and in the nearby boundaries of India and Burma included in Eastern Asiatic Region. This number is considerably higher than in all other regions, suggesting that the Eastern Asiatic Region could take an important role in diversification of Maloideae. The ensemble of Indochinese, Malaysian and Indian Regions have a set of genera which are also present in the Eastern Asiatic Region and show more mesophyllic requirements (Dichotomanthes, Docynia, Eriobotrya, Osteomeles, Photinia, Pyracantha and Rhaphiolepis). The Mediterranean, Irano-Turanian and Circumboreal 
Regions have a quite similar composition, only lacking Cydonia in the Mediterranean Region (Browicz, 1982, 1996). The Madrean Region is one of highest endemicity (the other is the Eastern Asiatic) with Heteromeles, Malacomeles and Peraphyllum. The genera in common between the Caribbean and the Madrean Region are: Crataegus, Hesperomeles, Malacomeles and Photinia, the latter genus being the only representative of Maloideae in the Andean Region. Most of the Madrean, Caribbean and Andean taxa are mesophyllic, showing an evergreen foliage, such as Hesperomeles, Heteromeles, Malacomeles and some species of Photinia.

\section{DISCUSSION}

\section{Phylogenetic relationships}

The classification of Maloideae proposed by Koehne (1890) was based on the absence or presence of pyrenes. This structure, derived from the concentration of sclereids in the centre of the pome, is usually related to seed protection during their passage through the digestive tract of animals involved in zoochory (Herrera, 1989). Hutchinson (1964) and Kalkman (1988) did not recognize subgroups in Rosaceae. Hutchinson (1964) included all genera in the tribe Pomeae (= Maleae). Kalkman (1988) accepted Hutchinson's proposal but separated a group formed by Chaenomeles, Cydonia, Docynia and Pseudocydonia characterized by multiovulated carpels. These authors and also Robertson et al. (1991), Phipps et al. (1991) and Campbell et al. (1995), disavow the use of two tribes proposed by Koehne (1890).

The data obtained in our cladistic analysis also seem to disclaim Koehne's ordination, but they are in concordance with some of the clades obtained from ITS sequencing by Campbell et al. (1995). These data served to group Eriobotrya and Rhaphiolepis in a clade (beside Vauquelinia) separated from the other members of subfam. Maloideae. The affinity between both genera seems to be corroborated by shared pome and seed features, such as the rounded or oval seeds, and the absence of endosperm. No other member of subfam. Maloideae studied had such large seeds or lacked endosperm. Other shared character states were the small, generally isolated sclereids distributed unevenly in the flesh and the absence of a differentiated core. All these data support the separation of this branch from the rest of the subfamily.

Vauquelinia, with a dry fruit, is also very close to Eriobotrya and Rhaphiolepis (Campbell et al., 1995). The inclusion of Vauquelinia, Kageneckia and several other Spiraeoideae in subfam. Maloideae was previously recommended by Goldblatt (1976), Morgan et al. (1994) and Takhtajan (1997), and the discovery of a fossil closely related to both groups, Paleorosa similkameensis, served to avail this idea (Basinger, 1976; Evans \& Campbell, 2002). Also the studies by Evans \& Dickinson (1999) about floral anatomy of Spiraeoideae showed characters, such as the ovules with a papillate funicular obturator, and the development of the gynoecium from a ring primordium, which support the inclusion of these genera in an expanded subfam. Maloideae. However, other features of both genera do not favour this treatment. In our opinion, the most important are: dry capsular fruits, winged seeds which present endosperm, and different wood ray anatomy (Zhang, 1992), characters shared by several other Spiraeoideae. Consequently, we prefer to exclude Vauquelinia and Kageneckia from subfam. Maloideae, at least for the moment. 
Another coincidence among our data, Campbell's analysis (Campbell et al. 1995) and the morphological studies by Robertson et al. (1991), was the clade of Amelanchier, Peraphyllum and Malacomeles. These plants share a pseudoberry pome and false septa in the locules. Additionally, in the group formed by the taxa with pyrenes, four genera with several Crataegus-type pyrenes are well supported. However, according to Campbell et al. (1995) a part of this clade (Crataegus-Mespilus) could be the sister group of the Amelanchier-Malacomeles clade.

The remaining genera of Maloideae form a polytomy that shows the scarcity of phylogenetically informative characters. However, three groups seem to merit a commentary: the group of species with pyrenes, the group Pyrus-Cydonia-Pseudocydonia and the subgenera of Sorbus. The eight genera with pyrenes (character 7, states 1, 2 and 3) do not appear as a clade in our consensus tree, suggesting that sclereids could group and originate pyrenes more than one time in the evolution.

The group Pyrus-Cydonia-Pseudocydonia also does not appear as monophyletic in the consensus tree, but is supported by a synapomorphic character: the large irregular groups of sclereids (character 6, state 2) and other: the pit surrounding the styles (character 4) which reverse in Pseudocydonia. Campbell et al. (1995) data, showed a Cydonia-Pseudocydonia clade. Several authors suggested that Pyrus may have branched from the ancestor of Cydonia and Pseudocydonia before the latter two taxa acquired the pluriovulate condition (Iketani \& Ohashi, 1991; Aldasoro et al., 1998a). Robertson et al. (1991) related Chaenomeles, Docynia, and Pseudocydonia to Malus and Campbell et al. (1995) presented Chaenomeles, Heteromeles, Malus, Photinia and Pyrus in the same clade, which is separated from that of Cydonia and Pseudocydonia. Our morphological data do not support any of these hypothesis, because Chaenomeles, Docynia and Malus sect. Docyniopsis differ from Pyrus in having more than 40 stamens, and Docynia, Malus and Malus sect. Docyniopsis differ from Pyrus in having Phloridzin.

Delimitation of Sorbus is a controversial topic (Robertson et al., 1991). The four subgenera included in Sorbus were analyzed as independent terminal taxa in order to explore their phylogenetic relationships. In the consensus tree the four subgenera appeared in the basal polytomy. Sorbus monophyly is not reasonably supported here nor is there persuasive evidence in favour of its splitting.

\section{Fossil record and present distribution}

Kalkman (1988) reported that the Spiraeoideae Vauquelinia and other related genera belong to a clade that should be considered as sister group of the core of Maloideae. These relationships seem to be confirmed by several ways: 1) by phytochemical evidences (Challice, 1973), since Lindleya shares with Maloideae the presence of flavone C-gycosides; 2) by DNA evidence (Campbell et al., 1995; Evans \& Campbell, 2002; Potter et al., 2002) such as ITS sequence data which showed differences between Vauquelinia and Rhaphiolepis only at 3.6\% of the sites (Campbell et al., 1995); and 3 ) by analyses of flower development (Evans \& Dickinson, 1999).

Maloideae could arise in some parts of Western Laurasia, since most of closely related Spiraeoideae grow in North America (Lindleya, Lyonothamnus A. Gray and Vauquelinia), only Kageneckia grows in South America. Relationships of the South American Spiraeoideae (mainly Kageneckia) to various northern genera are of inter- 
est, they can be related to North American Lindleya, Lyonothamnus and Vauquelinia, (Banwar, 1966; Raven \& Axelrod, 1974). The last three genera belong to an ensemble of xerophilous taxa, mainly evergreen sclerophyllous shrubs or small trees, which inhabited for a long time the western coast of North America. Leaves of Lyonothamnus and Vauquelinia are very well recorded in western USA during most of the Palaeogene (Axelrod, 1944, 1958, 1991; MacGinitie, 1953, 1969).

Hybridization has been hypothesized in the genesis of Maloideae and is currently extensive among several genera (Gladkova, 1972; Robertson et al., 1991). This led some authors to consider that a basal reticulation due to intergeneric hybridization could be related with their phylogenetic origin. Sax (1931) proposed an alloploid event to explain their origin, with a Spiroideae ancestor $(x=9)$ and a Prunoideae ancestor $(\mathrm{x}=8)$, which is supported by some anatomical and cytogenetic data (Stebbins, 1950; Challice \& Kovanda, 1981). Nevertheless, neither DNA nor wood anatomy data did easily support this view and they may better suggest that Maloideae descend entirely from Spiroideae ancestors such as Kageneckia or Vauquelinia (Zhang, 1992; Morgan et al., 1994; Campbell et al., 1995; Evans \& Dickinson, 1999; Evans \& Campbell, 2002).

Unfortunately, anatomical and morphological data studied here are not sufficient to explain the current distribution of genera and the evolution of most character states in the subfamily. Several taxa during the Early Tertiary belong to genera with pyrenes (as Crataegus and Pyracantha). This is consistent with the hypothesis of Iketani \& Ohashi (1991) who postulated that the pome of Pyracantha is the most primitive and the taxa included in Crataegeae are more primitive than those in Sorbeae. Other authors think that Dichotomanthes has a more primitive type of pome, in which the carpels are free from the hypanthium in spite of having other derivative traits, such as the solitary carpel with tomentose lateral stylodium (Gladkova, 1969, 1972; Takhtajan, 1997). However, our cladistic analysis favours Eriobotrya-Rhaphiolepis as sister group to the rest of Maloideae, including Dichotomanthes. This clade has some primitive states, including isolated sclereids, high seed/pome length ratio (also shared by the Amelanchier group), and evergreen leaves (also shared by several other genera), and they have also derivative features such as the lack of endosperm and seed shape.

If we see the present geographical distribution of Maloideae, a high number of genera (15) is outspread in an area including the South and South-East of China, and in the nearby boundaries of India and Burma, included in the Eastern Asiatic Region (Fig. 5). The core of subfamily Maloideae is essentially distributed in the Northern Hemisphere and better represented in subtropical areas of eastern Asia, where it could form a part of the Tertiary Laurasian Boreotropical flora (Tiffney, 1985). Most of early Tertiary floras of Asia have tropical-subtropical characteristics in common and included several Maloideae (Hsu, 1983; Ming-hong et al., 1983; Leopold et al., 1992; Guo, 1993). The presence in Indochina and Malaysia of Eriobotrya and Rhaphiolepis (included in the clade which is sister group of the rest of the subfamily) is congruent with an earlier separation of this clade and could be due to the retreat of a part of the oldest Palaeogene flora to the refuges of China, Indochina and Malaysia, while many wet-temperate forests were progressively transformed in many parts of Eurasia during a part of the Palaeogene and the Neogene (Tiffney, 1985). Both genera were found in north-eastern Siberia and northern China in Miocene sediments (see Table 2). 
As commented, during the Neogene, forest xerophilization progressed in areas of Central and Northern China, Trans-Caucasia, Middle Asia, Turkey, Iran and South and East Europe, while the remnants of old Tertiary flora occupied separated refuges, such as south-eastern China, Indochina, Malaysia, Caucasus, southern Japan, western North America and northern Central America (Raven \& Axelrod, 1974; Hsu, 1983; Tiffney, 1985), and the new xerophilic taxa spread to Caucasus, Siberia, Europe, and the drier parts of China and the Himalayas (Takhtajan, 1941, 1946; Gabrielian, 1961, 1978). Many of the genera of Maloideae would had to accommodate to these progressively xeric habitats.

A possible line of migration is the link between the Eastern Asia Region and the rest of the Holarctic Kingdom. Western North America and Eastern Asia probably shared a tropical-subtropical flora related to a Palaeogene linkage between the two areas, involving North Atlantic land bridges (Wolfe, 1975; Tiffney, 1985). The phylogenetic relationships do not always render a satisfactory explanation about the possible biogeographical episodes in the distribution of several taxa of the subfamily. However, some traits can be supposed: the well-supported clade of Malacomeles-Peraphyllum-Amelanchier, sharing the pomes with false septa, suggests an early pass to western North America. Also the disjunct distribution of Photinia could help this hypothesis. Several of these plants are adapted to sclerophyllous forests, and they were found fossil in Early or Middle Tertiary formations of western North America. This is the case with Heteromeles, Peraphyllum and Photinia (Table 2).

According to Raven \& Axelrod (1974) Hesperomeles originated in North America and migrated into north-western South America. The only known report of this genus is a pollen record from the Late Pliocene of Colombia (Wijninga \& Kuhry, 1993). As Crataegus is well represented in Eastern Asiatic flora and several features are shared by Crataegus, Mespilus and Hesperomeles (i.e. superposed ovules, pyrenes with flesh, and several layers of endosperm), the closest relative of Hesperomeles could be some primitive Crataegus (Phipps, 1983). In the case of Chamaemeles a long-distance dispersion can be postulated since it is strictly endemic of Madeira Island. However, the ancestor of this remarkable genus remains uncertain, because no current taxa of Maloideae has evergreen leaves, folded cotyledons and a solitary pyrene with one seed, but these character states could have been present in an ancestor of Crataegus from Middle Tertiary European coasts. The current distribution of Osteomeles can be explained only by long distance dispersal, which also seems the case for most Pacific Islands' taxa. The flora of Hawaii is also formed by taxa mainly coming in from East Asia (Fosberg, 1948).

The ultimate evaluation of the evolutionary hypotheses here developed, will be their congruence with other more elaborated datasets. Despite the seemingly high level of homoplasy (Phipps et al., 1991; Aldasoro et al., 1998a) a cladistic analysis of morphological and anatomical characters provides partial resolution among some genera of Maloideae that seems to be congruent with information from DNA sequence phylogenies and biogeography.

\section{ACKNOWLEDGEMENTS}

The authors thank M. Jerez for aiding photo and microscopy preparations. L. Rico is thanked for helpful criticisms of the manuscript. We also thank V. Plana, L. Rico and J. Muñoz for their bibliographic assistance. We are indebted to the curators of the following herbaria and living collections for 
the loan of specimens: Royal Botanic Gardens, Kew, Herbarium, Conservatoire et Jardin Botanique de la Ville de Genève, Sir Harold Hillier Gardens and Arboretum, Jardim Botanico da Madeira, and The University of Liverpool Botanic Gardens, Ness. This work was partly financed by the Spanish DGICYT through the research project PB96-08-49.

\section{REFERENCES}

Akhmetjev, M.A. 1973. Sikhote-Alin Miocene Flora (r. Botchi). Transactions Acad. Sci. USSR, 247: 1-123. [In Russian.]

Aldasoro, J.J., C. Aedo \& F. Muñoz Garmendia. 1996. The genus Pyrus L. (Rosaceae) in south-west Europe and North Africa. Bot. J. Linn. Soc. 121: 143-158.

Aldasoro, J.J., C. Aedo \& C. Navarro. 1998a. Pome anatomy of Pyrus (Rosaceae: Maloideae). Ann. Missouri Bot. Gard. 85: 518-527.

Aldasoro, J.J., C. Aedo, C. Navarro \& F. Muñoz Garmendia. 1998b. The genus Sorbus (Maloideae, Rosaceae) in Europe and in North Africa: morphological analysis and systematics. Syst. Bot. 23: $189-212$.

Alexander, M.P. 1980. A versatile stain for pollen, fungi, yeast and bacteria. Stain Technol. 55: $13-18$

Axelius, B. 1991. Areas of distribution and areas of endemism. Cladistics 7: 197-199.

Axelrod, D.I. 1944. The Mulholand flora. In: R.W. Chaney (ed.), Pliocene floras of California and Oregon. Publ. Carnegie Inst. Wash. 553:103-146.

Axelrod, D.I. 1958. Evolution of the Madro-Tertiary geoflora. Bot. Rev. 24: 433-509.

Axelrod, D.I. 1987. The Late Oligocene Creede flora, Colorado. Univ. Calif. Publ. Geol. Sci. 130: $1-235$.

Axelrod, D.I. 1991. The Early Miocene Buffalo Canyon flora of Western Nevada. Univ. Calif. Publ. Geol. Sci. 135: 1-76.

Axelrod, D. I. 1992. The Middle Miocene Pyramid flora of Western Nevada. Univ. Calif. Publ. Geol. Sci. 137: 1-50.

Axelrod, D.I. 1995. The Miocene Purple Mountain flora of Western Nevada. Univ. Calif. Publ. Geol. Sci. 139: 1-62.

Axelrod, D.I. 1998. The Eocene Thunder Mountain flora of central Idaho. Univ. Calif. Publ. Geol. Sci. 142: 1-61

Baikovskaja, T.N. 1974. Upper Miocene flora of the Southern Primorski Kray. Acad. Sci. SSSR, Leningrad. [In Russian.]

Banwar, S.C. 1966. Morphological and anatomical studies on the genus Lyonothamnus. PhD dissertation. Univ. California Press, Berkeley.

Basinger, J.F. 1976. Paleorosa similkameensis, gen. et sp. nov. permineralized flowers (Rosaceae) from the Eocene of British Columbia. Canad. J. Bot. 54: 2293-2305.

Becker, H.F. 1961. Oligocene Plants for the Upper Ruby River Basin, southwestern Montana. Mem. Geol. Soc. Amer. 82: 1-127.

Browicz, K. 1969. Distribution of woody Rosaceae in W. Asia III. Arbor. Kornickie 14: 5-23.

Browicz, K. 1971. Distribution of woody Rosaceae in W. Asia VII. Arbor. Kornickie 16: 5-26.

Browicz, K. 1982. Chorology of trees and shrubs in South-west Asia and adjacent regions I. Polish Scientific Publishers Pozna, Warszawa.

Browicz, K. 1992. East-West Euroasiatic disjunction of woody genera. Arbor. Kornickie 37: 5-19.

Browicz, K. 1996. Chorology of trees and shrubs in South-west Asia and adjacent regions. Polish Suppl. Scientific Publishers Pozna, Warszawa.

Budantzev, L.Y. 1959. Oligocene Flora of the North Aralian region. Problems of Botany, Vol. 4. Moscow-Leningrad.

Campbell, C.S., M.J. Donoghue, B.G. Baldwin \& M.F. Wojciechowski. 1995. Phylogenetic relationships in Maloideae (Rosaceae): evidence from sequences of the internal transcribed spacers of nuclear ribosomal DNA and its congruence with morphology. Amer. J. Bot. 82: 903-918.

Challice, J.S. 1973. Phenolic compounds of the subfamily Pomoideae: a chemotaxonomic survey. Phytochemistry 12: 1095-1101. 
Challice, J.S. 1974. Rosaceae chemotaxonomy and the origins of the Pomoideae. Bot. J. Linn. Soc. 69: 239-259.

Challice, J.S. \& M. Kovanda. 1981. Chemotaxonomic studies in the family Rosaceae and the evolutionary origins of the subfamily Maloideae. Preslia 53: 289-304.

Cevallos-Ferriz, S.R.S., D.M. Erwin \& R.A. Stockey. 1993. Further observations of Paleorosa similkameensis (Rosaceae) from the middle Eocene Princeton chart of British Columbia. Rev. Palaeobot. Palynol. 78: 277-291.

Danilova, M. 1996. Dicotiledones. Rosidae I. In: A. Takhtajan, Mir \& Semja (eds.), Anatomia seminum comparativa 5: 102-125. Petropoli. [In Russian.]

Decaisne, J. 1874. Mémoirs sur la famille des Pomacées. Nouv. Arch. Mus. Hist. Nat. 10: 113-192, pl. 8-15.

Depape, G. 1922. Recherches sur la Flore Pliocéne de la Vallée du Rhône. Ann. Sci. Nat., Bot., sér. 10, 4: 73-265.

Dunn, G. \& B.S. Everitt. 1982. An introduction to mathematical taxonomy. Cambridge University Press, Cambridge.

Eberle, G. 1965. Pflanzen am Mittelmeer. Mediterrane Pflanzengemeinschaften Italiens mit Ausblick auf das ganze Mittelmeergebiet. Kramer, Frankfurt am Main.

Ernst, A. 1906. Das Ergrünen der Samen von Eriobotrya japonica (Thbg.) Lindl. Beih. Bot. Centralbl. 19: $117-130$.

Evans, R.C. \& C.S. Campbell. 2002. The origin of the apple subfamily (Maloideae: Rosaceae) is clarified by DNA sequence data from duplicated GBSSI genes. Amer. J. Bot. 89: 1478-1484.

Evans, R.C. \& T. Dickinson. 1999. Floral ontogeny and morphology in subfamily Spiraeoideae Endl. (Rosaceae). Int. J. Pl. Sci. 160: 981-1012.

Felsenstein, J. 1985. Confidence limits on phylogenies: an approach using the bootstrap. Evolution 39: 783-791.

Forman, L. \& D. Bridson. 1989. The herbarium handbook. Kew.

Fosberg, F.R. 1948. Derivation of the flora of the Hawaiian islands. In: E.C. Zimmerman (ed.), Insects of Hawaii: 107-119. Honolulu.

Foster, S.A. 1986. On the adaptative value of large seeds for tropical moist forest trees: A review and synthesis. Bot. Rev. 52: 260-299.

Gabrielian, E. 1961. The genus Sorbus L. in Turkey. Notes Roy. Bot. Gard. Edinburgh 23: 483496.

Gabrielian, E. 1978. Rjabiny (Sorbus L.) Zapadnoj Azii i Gimalaev. Erevan. [In Russian.]

Gladkova, V.N. 1969. On the systematic position of the genus Dichotomanthes. Bot. Zhurn. (Moscow \& Leningrad) 54: Kurz. 431-436. [In Russian.]

Gladkova, V.N. 1972. On the origin of subfamily Maloideae. Bot. Zhurn. (Moscow \& Leningrad) 57: 42-49. [In Russian.]

Goldblatt, P. 1976. Cytotaxonomic studies in the tribe Quillajeae (Rosaceae). Ann. Missouri Bot. Gard. 63: 200-206.

Gray, S.F. 1821. A natural arrangement of British plants, vol. 2. Baldwin, Cradock \& Joy, London.

Guo, S. 1986. An Eocene flora from the Relu Formation in Litang Country of western Sichuan and the history of Eucalyptus. In: H.L. Sun (ed.), Studies in Qinghai-Xizang (Tibet) Plateau, Special Issue of Hengduan Mountains Scietific Expedition, vol. 2: 69-73. Beijing Science \& Technology Press, Beijing.

Guo, S. 1993. The evolution of the cenozoic tropical monsoon climate and monsoon forests in southwestern China. In: N.G. Jablonski \& So Chak-Lam (eds.), Evolving landscapes and evolving biotas of east Asia since the mid-Tertiary. Centre of Asian Studies occasional papers and monographies 107. University Hong-Kong.

Hengeveld, R. 1990. Dynamic biogeography. Cambridge University Press, Cambridge.

Herrera, C.M. 1989. Frugivory and seed dispersal by carnivorous mammals, and associated fruit characteristics, in undisturbed Mediterranean habitats. Oikos 55: 250-262.

Hess, W.J. \& J. Henrickson. 1987. A taxonomic revision of Vauquelinia (Rosaceae). Sida 12: $101-163$. 
Holloway, J.D. \& N. Jardine. 1968. Two approaches to zoogeography: a study based on the distributions of butterflies, birds and bats in the Indo-Australian area. Proc. Linn. Soc. London 179: $153-188$.

Hsu, J. 1983. Late Cretaceous and Cenozoic vegetation in China, emphasizing their connections with North America. Ann. Missouri Bot. Gard. 70: 490-508.

Hsu, J. \& R.W. Chaney. 1940. A Miocene flora from Shantung province, China. Contr. Paleontol. Carnegie Inst. Wash. 507: 1-147. Washington.

Hutchinson, J. 1964. The genera of flowering plants. Clarendon Press, Oxford.

Iketani, H. \& H. Ohashi. 1991. Anatomical structure of fruits and evolution of the tribe Sorbeae in the subfamily Maloideae (Rosaceae). J. Jap. Bot. 66: 319-351.

Jun-rong, T. 1965. A late Eocene flora from the district Weinan of Central Shensi. Acta Bot. Sin. 13: $272-278$.

Jun-rong, T. \& D. Nai-qiu. 1982. Neogene flora of Tengchong basin in western Yunnan, China. Acta Bot. Sin. 24: 273-281.

Jun-rong, T. \& D. Nai-qiu. 1987. Miocene flora from Markam county and fossil record of Betulaceae. Acta Bot. Sin. 29: 649-655.

Kalkman, C. 1973. The Malesian species of the subfamily Maloideae (Rosaceae). Blumea 21: 413-442.

Kalkman, C. 1988. The phylogeny of the Rosaceae. Bot. J. Linn. Soc. 98: 37-59.

Koehne, E. 1890. Die Gattungen der Pomaceen. Berlin.

Kryshtopovich, A.N. \& T.N. Baikovskaja. 1965. Sarmatskaia Flora Krynki. Acad. Sci. SSSR, Moscow $\&$ Leningrad. [In Russian.]

Kruskal, J.B. \& M. Wish. 1978. Multidimensional scaling. California Sage, Beverly Hills.

Kulczynski, S. 1928. Die Pflanzenassoziationen der Pieninen. Bull. Int. Acad. Polon. Sci., Cl. Sci. Math., Ser. B, Sci. Nat., Suppl. II (1927): 57-203.

Lakhanpal, R.N. 1958. The Rugada flora of west central Oregon. Univ. Calif. Publ. Geol. Sci. 35: $1-66$.

Lakhanpal, R.N 1970. Tertiary Floras of India and their bearing on the historical geology of the region. Taxon 19: 675-694.

Leopold, E.B., G. Liu \& S. Clay-Pole. 1992. Low-biomass vegetation in the Oligocene? In: D.R. Prothero \& W.A. Berggren (eds.), Eocene-Oligocene climatic and biotic evolution: 399-435. Princeton University Press, Princeton \& Oxford.

Li, H.M. \& S. Guo. 1976. The Miocene flora from Namling County of Xizang. Acta Palaeontol. Sin. 15: 7-18

Likhonos, F.D. 1974. A survey of the species in the genus Malus Mill. Bot. Zhurn. (Moscow \& Leningrad) 53: 16-34. [In Russian.]

Lindley, J. 1822. Observations on the natural group of plants called Pomaceae. Trans. Linn. Soc. London 13: 88-106.

MacGinitie, H.D. 1953. Fossil plants of the florissant beds, Colorado. Publ. Carnegie Inst. Wash. 599: 1-197.

MacGinitie, H.D. 1969. The Eocene Green River flora of northwestern Colorado and northeastern Utah. Univ. Calif. Publ. Geol. Sci. 83: 1-140.

Maddison, W.P. \& D. R. Maddison. 1992. MacClade: Analysis of phylogeny and character evolution. Version 3.0. Sunderland. Sinauer Associates, Massachusetts.

Mai, D.H. \& H. Walther. 1978. Die Floren der Haselbacher Serie im Weisselster-Beccken (Bezirk Leipzig, DDR). Abh. Staatl. Mus. Mineral. Geol. Dresden 28: 1-101.

Manchester, S.R. 1999. Biogeographical relationships of North American Tertiary floras. Ann. Missouri Bot. Gard. 61: 539-673.

Meyer, H.W. \& S.R. Manchester. 1997. The Oligocene Bridge Creek Flora of the John Day Formation, Oregon. Univ. Calif. Publ. Geol. Sci. 141: 1-191.

Ming-hong, C.K. Zhao-chen \& C. Ye. 1983. On the discovery of palaeogene flora from the western Sichuan plateau and its significance in phytogeography. Acta Bot. Sin. 25: 482-491. [In Chinese.] 
Morgan, D.R., D.E. Soltis \& K.R. Robertson. 1994. Systematic and evolutionary implications of rbcL sequence variation in Rosaceae. Amer. J. Bot. 81: 890-903.

Ozaki, K. 1991. Late Miocene and Pliocene floras in central Honshu, Japan. Bull. Kanagawa Pref. Mus., Nat. Sci., Special Issue.

Péchoutre, F. 1902. Contribution à l'étude du développement de l'ovule et de la graine des Rosacées. Ann. Sci. Nat., Bot., sér. 8, 16: 1-145.

Phipps, J.B. 1983. Biogeographic, taxonomic, and cladistic relationships between East Asiatic and North American Crataegus. Ann. Missouri Bot. Gard. 70: 667-700.

Phipps, J.B. 1990. Mespilus canescens, a new Rosaceous endemic from Arkansas. Syst. Bot. 15: $26-32$.

Phipps, J.B., K.R. Robertson, J.R. Rohrer \& P.G. Smith. 1991. Origins and evolution of subfam. Maloideae (Rosaceae). Syst. Bot. 16: 303-332.

Phipps, J.B., K.R. Robertson, P.G. Smith \& J.R. Rohrer. 1990. A checklist of the subfamily Maloideae (Rosaceae). Canad. J. Bot. 68: 2209-2269.

Potter, D., F. Gao, P. Esteban Bortiri, S.-H. Oh \& S. Baggett. 2002. Phylogenetic relationships in Rosaceae inferred from chloroplast matK and trnL-trnF nucleotide sequence data. Pl. Syst. Evol. 231: 77-89.

Primack, R.B. 1987. Relationships among flowers, fruits, and seeds. Annual Rev. Ecol. Syst. 18: 409-430.

Raven, P. \& D.I. Axelrod. 1974. Angiosperm biogeography and past continental movements. Ann. Missouri Bot. Gard. 61: 539-673.

Rehder, A. 1920. New species, varieties and combinations from the herbarium and the collections of the Arnold Arboretum. J. Arnold Arbor. 1: 254-263.

Rehder, A. 1940. Manual of cultivated trees and shrubs hardy in North America exclusive of the subtropical and warmer temperate regions. Second edition. Macmillan Publishing Co, New York.

Robertson, K.R., J.B. Phipps, J.R. Rohrer \& P.G. Smith. 1991. A synopsis of genera in Maloideae (Rosaceae). Syst. Bot. 16: 376-394.

Rohlf, F.J. 1992. NTSYS-pc, Numerical Taxonomy and Multivariate Analysis System, version 1.70. Exeter Software, New York.

Rohrer, J.R., K.R. Robertson \& J.B. Phipps. 1991. Variation in structure among fruits of Maloideae (Rosaceae). Amer. J. Bot. 78: 1617-1635.

Rohrer, J.R., K.R. Robertson, \& J.B. Phipps. 1994. Floral morphology of Maloideae (Rosaceae) and its systematic relevance. Amer. J. Bot. 81: 574-581.

Sax, K. 1931. The origin and relationships of Pomoideae. J. Arnold Arbor. 12: 3-22.

Stapf, O. 1910. Micromeles caloneura. Bot. Mag. 136, t. 8335.

Stebbins, G.L. 1950. On the hybrid origin of the angiosperms. Evolution 58: 267-270.

Sterling, C. 1964. Comparative morphology of the carpel in the Rosaceae. III. Pomoideae: Crataegus, Hesperomeles, Mespilus, Osteomeles. Amer. J. Bot. 51: 705-712.

Sterling, C. 1965a. Comparative morphology of the carpel in the Rosaceae. IV. Pomoideae: Chamaemeles, Cotoneaster, Dichotomanthes, Pyracantha. Amer. J. Bot. 52: 47-54.

Sterling, C. 1965b. Comparative morphology of the carpel in the Rosaceae. V. Pomoideae: Amelanchier, Aronia, Malacomeles, Peraphyllum, Pyrus, Sorbus. Amer. J. Bot. 52: 418-426.

Sterling, C. 1965c. Comparative morphology of the carpel in the Rosaceae. VI. Pomoideae: Eriobotrya, Heteromeles, Photinia, Pourthiaea, Rhaphiolepis, Stranvaesia. Amer. J. Bot. 52: 938-946.

Sterling, C. 1966. Comparative morphology of the carpel in the Rosaceae. IX. Spiraeoideae: Quillajeae, Sorbarieae. Amer. J. Bot. 53: 951-960.

Swofford, D.L. 1998. PAUP: Phylogenetic Analysis Using Parsimony (and other methods), version 4.0. Sinauer Associates, Sunderland.

Szafer, W. 1954. Pliocene Flora from the vicinity of Czorsztyna (West Carpathians) and its relationships to the Pleistocene. Wydaw. Geol. Warszawa 11: 5-239.

Szafer, W. 1961. Miocene Flora from Stare Gliwice in Upper Silesia. Wydaw. Geol. Warszawa 33: 5-197.

Takhtajan, A. 1941. Phytogeographic survey on Armenian SSR. Trudy Bot. Inst. Armyansk. Fil. Akad. Nauk. SSSR 2: 1-153. 
Takhtajan, A. 1946. On the history of development of vegetation of Armenia. Trudy Bot. Inst. Armyansk. Fil. Akad. Nauk. SSSR 4: 51-107.

Takhtajan, A. 1986. Floristic regions of the world. University California Press, California.

Takhtajan, A. 1997. Diversity and classification of flowering plants. Columbia University Press, New York.

Takhtajan, A., V.A. Vakhrameev \& G.P. Radchenko. 1963. Osnovy Paleontologii Spravochnik. Dlya Paleontologov I Geologov SSSR. Moskva. [In Russian.]

Taylor, D.W. 1990. Paleobiogeographic relationships of Angiosperms from the Cretaceous and Early Tertiary of the North American Area. Bot. Rev. 56: 279-417.

Thorne, R.F. 1983. Proposed new realignments in the angiosperms. Nordic J. Bot. 3: 85-117.

Tiffney, B.H. 1984. Seed size dispersal syndromes, and the rise of the Angiosperms: evidence and hypothesis. Ann. Missouri Bot. Gard. 71: 551-576.

Tiffney, B.H. 1985. The Eocene north Atlantic land bridge: its importance in tertiary and modern phytogeography of the northern hemisphere. J. Arnold Arbor. 66: 243-273.

Tolivia, D. \& J. Tolivia. 1987. Fasga: a new polychromatic method for simultaneous and differential staining of plant tissues. J. Microscopy 148: 113-117.

Tsun-shen, Y., Z. Yu-long \& D.E. Boufford. 1993. The endemic genera of seed plants of China. Science Press, Beijing.

Van Steenis, C.G.G.J. \& M.M.J. van Balgooy. 1966. Pacific Plant Areas 2. Blumea Suppl. 5: $1-310$.

Vidal, J.E. 1965. Notes sur quelques Rosacées asiatiques (III). Révision du genre Eriobotrya (Pomoideae). Adansonia 5: 537-580.

Watrous, L.E. \& Q.L. Wheeler. 1981. The outgroup comparison method of character analysis. Syst. Zool. 30: 1-11.

Weber, C. 1964. The genus Chaenomeles (Rosaceae). J. Arnold Arbor. 45: 161-295, 302-345.

Wijninga, V.M. \& P. Kuhry. 1993. Late Pliocene paleoecology of the Guasca Valley (Cordillera Oriental, Colombia). Rev. Palaeobot. Palynol. 78: 69-127.

Williams, A.H. 1982. Chemical evidence from flavonoids relevant to the classification of Malus species. Bot. J. Linn. Soc. 84: 31-39.

Wolfe, J.A. 1972. An interpretation of Alaskan Tertiary Floras. In: A. Graham (ed.), Floristic and Palaeofloristics of Asia and Eastern North America. 201-233. Elsevier Publishing Company, Amsterdam, London, New York.

Wolfe, J.A. 1975. Some aspects of plant geography of the Northern hemisphere during the late Cretaceous and Tertiary. Ann. Missouri Bot. Gard. 62: 264-279.

Wolfe, J.A. 1977. Paleogene floras from the Gulf of Alaska region. Profess. Pap. U.S. Geol. Surv. 997: $1-108$.

Wolfe, J.A. \& W. Wehr. 1987. Middle Eocene dicotyledonous plants from Republic, northeastern Washington. Profess. Pap. U.S. Geol. Surv. 1597: 1-25.

Zhang, S.-Y. 1992. Systematic wood anatomy of the Rosaceae. Blumea 37: 81-158.

Zhang, S.-Y. \& P. Baas. 1992. Wood anatomy of trees and shrubs from China. IAWA Bull. n.s. 13: 21-91.

Zhilin, S.G. 1974. Trechnye flory Ustyurta. Leningrad.

Zhilin, S.G. 1989. History of the development of the temperate forest flora in Kazakhstan, USSR from the Oligocene to the Early Miocene. Bot. Rev. 55: 205-330. 
APPENDIX. List of species whose seeds were examined: binomials, authorities, collectors, collection numbers, and location of voucher specimens as indicated by herbarium acronym.

Amelanchier canadensis (L.) Medik., Aldasoro 721 (MA-580305)

Amelanchier ovalis Medik., Aedo 3451 (MA-555587)

Chamaemeles coriacea Lindl., Fernandes \& Jardim 8677 (MA-593013)

Chaenomeles cathayensis (Hemsl.) C.K. Schneid., Aldasoro 725 (MA-580296)

Chaenomeles japonica (Thunb.) Lindl., Aldasoro 544 (MA-580297)

Cotoneaster buxifolius Wall. ex Lindl., Aedo 3891 (MA-580425)

Cotoneaster integerrimus Medik., Aldasoro 580 (MA-580292)

Cotoneaster salicifolius Franch., Aedo 3890 (MA-580424)

Crataegus azarolus L., Soler 779 (MA-580441)

Crataegus maineana Sarg., Aldasoro 688 (MA-580301)

Crataegus mollis Scheele, Aldasoro 723 (MA-580299)

Crataegus monogyna Jacq., Soler 778 (MA-580446)

Crataegus oresbia W.W. Sm., Aldasoro 689 (MA-580303)

Crataegus pentagyna Waldst. \& Kit., Aldasoro 682 (MA-580304)

Crataegus phaenopyrum (L.f.) Medik., Aldasoro 722 (MA-580443)

Crataegus pruinosa (J.C. Wendl.) K. Koch, Aldasoro 692 (MA-580302)

Crataegus pubescens (Humb., Bonpl. \& Kunth) Steud., Hinton 4047 (MA-305100)

Crataegus x ruscinonensis Gren. \& Blanc, Soler 777 (MA-580445)

Cydonia oblonga Mill., Aldasoro 561 (MA-580295)

Dichotomanthes tristaniaecarpa Kurz, Aldasoro 726 (MA-580294)

Docynia delavayi C.K. Schneid., Aldasoro 729 (MA-580291)

Docynia indica (Wall.) Decne., Aldasoro 730 (MA-581070)

Eriobotrya angustissima Hook.f., Aldasoro 718 (MA-580309)

Eriobotrya benghalensis (Roxb.) Hook., Aldasoro 717 (MA-580310)

Eriobotrya japonica (Thunb.) Lindl., Aldasoro 715 (MA-580312)

Eriobotrya petiolata Hook., Aldasoro 714 (MA-580313)

Eriobotrya tengyuehensis W.W. Sm., Aldasoro 716 (MA-580311)

Hesperomeles ferruginea Lindl., Cuatrecasas 28890 (MA-507790)

Hesperomeles lanuginosa Hook., Cano 4179 (MA-515098)

Heteromeles salicifolia (C. Presl) Abrams, Bartholomew 1479 (MA-382438)

Kageneckia oblonga Ruiz \& Pav., Basualto, Gebanero \& Orellana 72 (MA-487971)

Lindleia mespilioides Kunth, Calzada 19673 (MA-614228)

Malacomeles denticulata (Knuth) G.N. Jones, Nicolás s.n. (G)

Malus baccata (L.) Borkh., Aldasoro 691 (MA-580307)

Malus florentina (Zucc.) C.K. Schneid., Aldasoro 634 (MA-580439)

Malus floribunda Siebold, Aldasoro 720 (MA-580306)

Malus fusca (Raf.) C.K. Schneid., Aldasoro 539 (MA-580435)

Malus halliana Koehne, Aldasoro 606 (MA-580442)

Malus ioensis (Wood) Britton, Aldasoro 719 (MA-580432)

Malus kansuensis (Batalin) C.K. Schneid., Aldasoro 681 (MA-580437)

Malus prunifolia (Willd.) Borkh., Aldasoro 603 (MA-580440)

Malus sargentii Rehder, Aldasoro 675 (MA-580433)

Malus sieboldii Rehder, Aldasoro 648 (MA-580447)

Malus sikkimensis Koehne ex C.K. Schneid., Aldasoro 689 (MA-580434)

Malus sylvestris (L.) Mill., Aldasoro 132 (MA-580290)

Malus trilobata (Labill.) C.K. Schneid., Aldasoro 665 (MA-580438)

Malus tschonoskii (Maxim.) C.K. Schneid., Aldasoro 643 (MA-580308)

Malus yunnanensis C.K. Schneid., Aldasoro 635 (MA-580436)

Mespilus germanica L., C. Navarro 1166 (MA-580289)

Osteomeles schwerinae C.K. Schneid., Aldasoro 724 (MA-580298)

Peraphyllum ramosissimum Nutt., Aldasoro 731 (MA-581071)

Photinia beauverdiana C.K. Schneid., Aldasoro 658 (MA-580213)

Photinia davidiana (Decne.) Cardot, Aldasoro 709 (MA-580211)

Photinia melanocarpa (Michx.) K.R. Robertson \& J.B. Phipps, Aldasoro 710 (MA-580202)

Photinia pyrifolia (Lam.) K.R. Robertson \& J.B. Phipps, Aldasoro 594 (MA-580209)

Photinia salicifolia C. Presl, Bartholomew 1479 (MA-382438)

Photinia serratifolia (Desf.) Kalkman, Aldasoro 708 (MA-580210)

Photinia villosa (Thunb.) DC., Aldasoro 678 (MA-580212) 
Pseudocydonia sinensis C.K. Schneid., Aldasoro 806 (MA-597421)

Pyracantha angustifolia C.K. Schneid., Aldasoro 728 (MA-580444)

Pyracantha coccinea M. Roem., Bolòs 546 (MA-341844)

Pyracantha crenatoserrata (Hance) Rehder, Aldasoro 727 (MA-580293)

Pyrus betulifolia Bunge, Aldasoro 670 (MA-579434)

Pyrus bourgaeana Decne., Aldasoro 131 (MA-579428)

Pyrus calleryana Decne., Aldasoro 707 (MA-579429)

Pyrus communis L., Monasterio et al. 1168 (MA-529106)

Pyrus cordata Desv., Aedo 2477 (MA-514838)

Pyrus elaeagnifolia Pall., Aldasoro 690a (MA-579437)

Pyrus georgica Kuth., unknown collector (MA-417326)

Pyrus nivalis Jacq., Aldasoro 644 (MA-579431)

Pyrus pashia Buch.-Ham. ex D. Don, Aldasoro 641 (MA-579430)

Pyrus phaeocarpa Rehder, Aldasoro 669 (MA-579438)

Pyrus pyrifolia (Burm.f.) Nakai, Aldasoro 667 (MA-579427)

Pyrus salicifolia Pall., Aldasoro 690 (MA-579433)

Pyrus spinosa Forssk., C. Navarro et al. 1405 (MA-579557)

Pyrus syriaca Boiss., Aldasoro 668 (MA-579435)

Pyrus ussuriensis Maxim., Aldasoro 676 (MA-579432)

Rhaphiolepis $\times$ delacourii André, Aldasoro 666 (MA-580314)

Rhaphiolepis indica (L.) Lindl., Aldasoro 713 (MA-580430)

Rhaphiolepis umbellata (Thunb.) Makino, Aldasoro 545 (MA-580431)

Sorbus alnifolia (Siebold \& Zucc.) K. Koch, Aldasoro 672 (MA-580223)

Sorbus aria (L.) Crantz, Aedo 3380 (MA-542774)

Sorbus aucuparia L., Aedo 3383 (MA-544275)

Sorbus caloneura (Stapf) Rehder, Aldasoro 687 (MA-580222)

Sorbus chamaemespilus (L.) Crantz, Aedo 3140 (MA-544290)

Sorbus commixta Hedl., Aldasoro 553 (MA-580221)

Sorbus domestica L., Aldasoro 560 (MA-580217)

Sorbus esserteauiana Koehne, Aldasoro 541 (MA-580220)

Sorbus folgneri (C.K. Schneid.) Rehder, Aldasoro 711 (MA-580315)

Sorbus forrestii H.A. McAllister \& C.M. Gillham, Aldasoro 602 (MA-580214)

Sorbus hajastana Gabrieljan, Aldasoro 679 (MA-580201)

Sorbus harrowiana (Balf.f. \& W.W. Sm.) Rehder, Aldasoro 637 (MA-580197)

Sorbus hedlundii C.K. Schneid., Aldasoro 639 (MA-580201)

Sorbus hemsleyi (C.K. Schneid.) Rehder, Aldasoro 699 (MA-582151)

Sorbus hupehensis C.K. Schneid., Aldasoro 550 (MA-580218)

Sorbus hybrida L., Aldasoro 453 (MA-543364)

Sorbus intermedia (Ehrh.) Pers., Aldasoro 485 (MA-543306)

Sorbus japonica (Decne.) Hedl., Aldasoro 704 (MA-580226)

Sorbus keissleri (C.K. Schneid.) Rehder, Aldasoro 652 (MA-580225)

Sorbus koehneana C.K. Schneid., Aldasoro 712 (MA-580429)

Sorbus lanata (D. Don) Schauer, Aldasoro 624 (MA-580203)

Sorbus latifolia (Lam.) Pers., Aldasoro 457 (MA-543362)

Sorbus megalocarpa Rehder, Aldasoro 674 (MA-580200)

Sorbus meliosmifolia Rehder, Aldasoro 660 (MA-580224)

Sorbus pallescens Rehder, Aldasoro 700 (MA-580202)

Sorbus reducta Diels, Aldasoro 638 (MA-580426)

Sorbus sargentiana Koehne, Aldasoro 623 (MA-580216)

Sorbus scalaris Koehne, Aldasoro 552 (MA-580219)

Sorbus subfusca (Ledeb.) Boiss., Aldasoro 653 (MA-580204)

Sorbus takhtajanii Gabrieljan, Aldasoro 680 (MA-580205)

Sorbus tamanschjanae Gabrieljan, Aldasoro 589 (MA-580215)

Sorbus thibetica (Cardot) Hand.-Mazz., Aldasoro 636 (MA-580428)

Sorbus tianshanica Rupr., Kuklina 15167 (MA-531756)

Sorbus torminalis (L.) Crantz, C. Navarro 1380 (MA-543440)

Sorbus vestita Lodd., Aldasoro 621 (MA-580207)

Sorbus vilmorinii C.K. Schneid., Aldasoro 629 (MA-580427)

Sorbus yuana Spongberg, Aldasoro 703 (MA-580198)

Sorbus zahlbruckneri C.K. Schneid., Aldasoro 702 (MA-580199)

Vauquelinia corymbosa Humb. \& Bonpl., Ventura \& López 9249 (MA-527389) 